\title{
A STUDY OF THE CARBOHYDRATES IN THE CELL WALLS OF SOME SPECIES OF THE ENTOMOPHTHORALES
}

\section{CENTRE FOR NEWFOUNDLAND STUDIES}

\section{TOTAL OF 10 PAGES ONLY MAY BE XEROXED}

(Without Author's Permission)

JOHN HODDINOTT, B.SC. (HONS) LONDON 


\section{0}




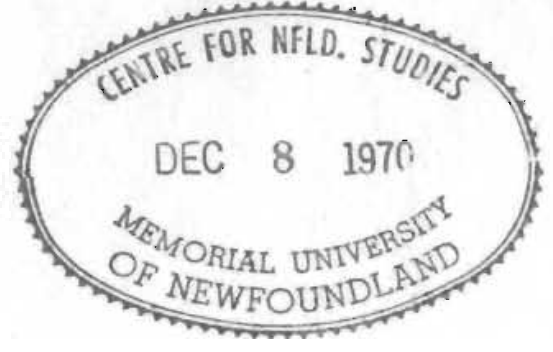





\title{
A STUDY OF THE CARBOHYDRATES IN THE CELL WALLS OF SOME SPECIES OF THE ENTOMOPHTHORALES
}

\footnotetext{
(c) John Hoddinott, B.Sc. (Hons.) London
}

\author{
Submitted in partial fulfilment \\ of the requirements for the degree of \\ Master of Science
}

Memorial University of Newfoundland

August, 1970 


\begin{abstract}
"There is one thing we know about chemical variation, it exists."
\end{abstract}

J. Brachet. 
CONTENTS

ABSTRACT . . . . . . . . . . . . . . .

ABBREVIATIONS

ACKNOWLEDGEMENTS

CHAPTER I - INTRODUCTION . . . . . . . . . . .

(ii)

(iii)

A. Review of Literature . . . . . . . 1

B. Outline of Research ........ 5

CHAPTER II - CULTURE AND SEPARATION TECHNIQUES . . . . . 10

A. Materials and Methods ........ 10

I. Sources of fungi ........ 10

II. Culture of fungi . . . . • . • 10

III. Separation of cell walls from cytoplasm 12

IV. Comparison of the efficiency of the separation methods ....... . 14

B. Results . . . . . . . . 17

I. Culture ........... 17

II. Separation . . . . . . . . 17

III. Comparison of the efficiency of the separation methods ........ 19

CHAPTER III-HISTOCHEMISTRY . • • • • • • • • • 21

A. Materials and Methods ........ 21

I. Tests on intact mycelium . . . . . 21

II. Tests on separated cell wall • . . . 22

B. Results . . . . . . . . 25

I. Tests on intact mycelium . . . . 25

II. Tests on separated cell wall . . . . 25 


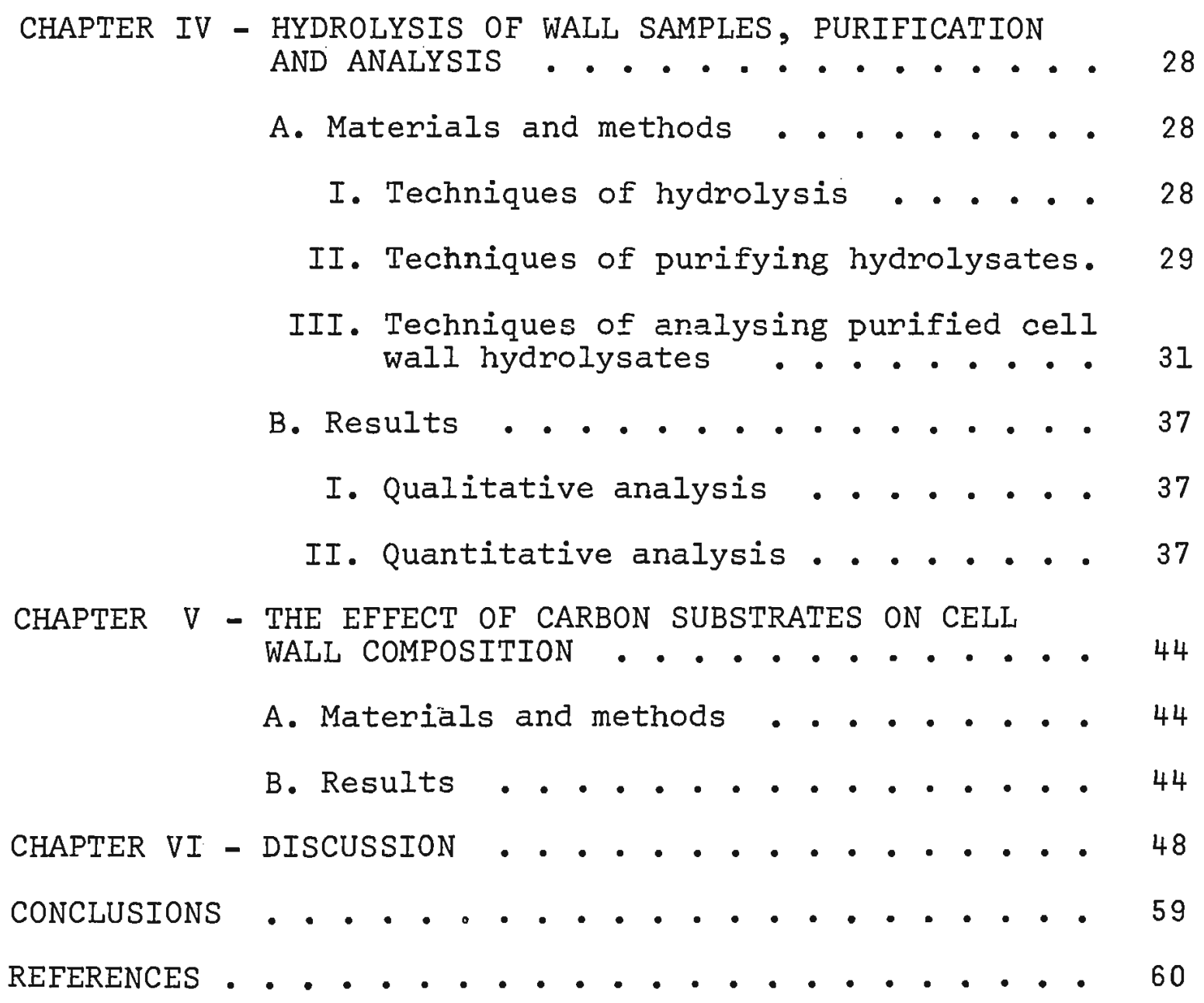




\section{LIST OF TABLES}

Table

Page

1. Cell wall taxonomy of fungi . . . . . . . . . 9

2. Comparison of media used for mass culture . • . . 18

3. Histochemical tests on efficiency of separation methods . . . . . . . . . . . . . . 20

4. Sequence of tests on isolated cell walls . . . . 24

5. Histochemical tests on intact mycelium . . . . . 26

6. Histochemical tests on separated cell wall • • - 27

7. $R_{F}$ values of glucosamine spots . . . . . . . 38

8. $R_{F}$ values of monosaccharides and their distribution among the fungal species . . . . . . . . . 38

9. $R_{F}$ values of glucuronic acid spots . • . . • . 38

10. Percentage composition of glucosamine in cell walls 40

11. Simple monosaccharide composition of the cell walls 41

12. Percentage composition of glucunonic acid in cell walls . . . . . . . . . . . . . 42

13. Percentage composition of non-nitrogenous sugar in cell walls . . . . . . . . . . . . . .

14a. Simple monosaccharide composition of the cell wall of $\underline{E}$. coronata on different carbon substrates . • 46

14b. Simple monosaccharide composition of the cell wall of E. thaxteriana on different carbon substrates. 


\section{LIST OF FIGURES}

Figure

Facing page 15

1. Entomophthora coronata, intact mycelium

2. E. coronata, sonicated mycelium

3. E. coronata, sonicated and washed mycelium

4. Entomophthora exitialis, intact mycelium

5. E. exitialis, sonicated mycelium

6. E. exitialis, sonicated and washed mycelium

7. Entomophthora thaxteriana, intact mycelium

8. E. thaxteriana, sonicated mycelium

9. E. thaxteriana, sonicated and washed mycelium

10. Entomophthora virulenta, intact mycelium

11. E. virulenta, sonicated mycelium

12. E. virulenta, sonicated and washed mycelium

13 Conidiobolus stromoideus, intact mycelium

14. C. stromoideus, sonicated mycelium

15. . . stromoideus, sonicated and washed mycelium

16. Basidiobolus ranarum, intact mycelium

17. B. ranivum, sonicated mycelium

18. B. ranarum, sonicated and washed mycelium 


\section{ABSTRACT}

The Entomophthorales were studied to determine whether a new criterion could be introduced into their scheme of classification to help clarify some of the synonymy within the group. An attempt was also made to see if differences in the cell wall carbohydrates showed any correlation with the differences in mycelial lipids within the group. It was also desirable to find out if the Entomophthorales were of similar cell wall composition to the Mucorales, and if not to which chemical category they should be assigned.

Several media were tested to see which one supported the best fungal growth, and several extraction techniques were tested to see which gave the most useful cell wall preparations free of cytoplasm. The efficiency of the cell wall extractions was determined histochemically.

A histochemical study of the cell wall was made to provide qualitative data on the constituent polysaccharides in the cell walls. Further qualitative data was gained by hydrolysing the cell walls and analysing by chromatography the monosaccharides so released. Quantitative data were gathered by analysing the hydrolysates by colourimetric techniques.

It was shown as a result of this study that qualitative differences occur between the genera tested, and that quantitative differences occur between the species of one genus. The glucose: mannose ratio is the most useful taxonomic criterion at the species level, as it remains constant on a variety of media. 
The sub-grouping of the Entomophthorales by their lipid composition seems to be reflected in the cell wall carbohydrate composition.

The Entomophthorales should not be classed chemically with the Mucorales; they should be separated into a category of chitin-glucan fungi. 
ABBREVIATIONS

The following abbreviations are used in this thesis.

E.c. - Entomophthora coronata

E.e. - Entomophthora exitialis

E.t. - Entomophthora thaxteriana

E.v. - Entomophthora virulenta

c.s. - Conidiobolus stromoideus

B.r. - Basidiobolus ranarum 


\section{ACKNOWLEDGEMENTS}

It is with gratitude that I acknowledge the gift of a specimen of Entomophthora thaxteriana by Dr. E. Müller-Kögler, Biologische Bundesanstalt für Land und Forstwirtschaft, Institut für Biologische Schädlingsbekampfung, Darmstadt, West Germany.

Thanks are extended to Dr. K.G. Reid of the Biochemistry Department of Memorial University for the loan of ion-exchange resins and an ion-exchange column.

I would like to thank all the members of the Departments of Biology and Biochemistry of Memorial University who made useful suggestions and criticisms. In this respect I would particularly like to thank Dr. G. Moskovits and Dr. P.J. O'Brien.

Finally, I would like to thank my supervisor, Dr. 0.A. Olsen, of the Biology Department of Memorial University, for his criticism, encouragement and guidance.

This work was carried out while I held a Departmental Fellowship in the Department of Biology of Memorial University. 
A STUDY OF THE CARBOHYDRATES IN THE CELL WALLS OF SOME SPECIES OF THE ENTOMOPHTHORALES

CHAPTER I-INTRODUCTION

Both Klein and Cronquist, 1967 and Bartnicki-Garcia, 1968 have emphasised the usefulness of cell wall studies in fungal systematics. The latter author observed that "the correlation between cell wall chemistry and taxonomy may be effectively extended to genus level" and he predicted that any differences would be mainly quantitative. The main purpose of the study reported in this thesis was to test the validity of this prediction for the Entomophthorales, and to attempt to extend it to the species level.

\section{A. Review of Literature}

The wall composition of vegetative cells of fungi has been the subject of a great deal of research over the past decade. (For reviews see Aronson, 1965 and Bartnicki-Garcia, 1968.) This work has yielded much useful information on the taxonomy of the major groups of fungi, and has led to the creation of a general system where many major groups of fungi are classified according to the two major polysaccharides found in the cell wall. At present eight chemical categories exist (Table I).

Comparative work on cell wall composition has not been widely undertaken at the lower taxonomic levels. Penicillium has been the genus most widely studied. The wall composition has been determined for $\underline{\mathrm{P}}$. notatum (Applegarth, 1967), $\underline{\mathrm{P}}$. roquefortii 
(Applegarth and Bozoian, 1968), $\underline{P} \cdot$ griseofulvum (Smithies, 1952), P. chrysogenum (Hamilton and Knight, 1962, and Rizzi and Kornfeld, 1969); $\underline{P}$. digitatum and $\underline{P}$. italicum (Grisaro et al, 1968). As the work was carried out by five independent groups using different culture, separation, and analytical techniques, it is difficult to draw comparisons between their data. The most detailed comparative study has been carried out by O'Brien and Ralph, 1966. They found that among the Polyporaceae the qualitative pattern of alkali-soluble material was not specific enough for the formulation of a taxonomic system, but that the quantitative pattern was of some taxonomic significance. For their alkali-insoluble material there was no relationship between quantitative composition and taxonomic position. As the Polyporaceae fall into Bartnicki-Garcia's chemical category (5) where the walls are predominantly made up of chitin and glucan, their results may not be applicable to other categories.

In addition to carbohydrates, proteins and lipids also occur as cell wall components. Bartnicki-Garcia and Nickerson, 1962 and Bartnicki-Garcia, 1966 have reported the presence of proteins in celI walls. Rizzi and Kornfeld, 1969 have analysed the amino acid content of the proteins in the cell walls of Pericillium chrysogenum, and Mitchell and Taylor, 1969 have compared the amino acids in the cell wall proteins of Aspergilius niger and Chaetomium globosum. Lipids have also been shown to be present by Bartnicki-Garcia and Nickerson, 1962 and Novaes-Ledieu et al, 1967. 
The first description of a fungus now classified in the Entomophthorales was made by Cohn, 1855. Unfortunately for later workers he named his fungus Empusa. In 1856 Fresenius rightly pointed out that since the name Empusa had been in use since 1824 to describe an orchid, its use to describe a fungus was incorrect. For this reason Fresenius suggested that the type genus be called Entomophthora. Instead of solving the problem of precedence, the work of Fresenius led to greater confusion as the reduction of Empusa to a synonym was not immediately accepted by all mycologists. The two names persisted as distinct genera. Nowakowski, 1883 regarded all types with branched conidiophores as Entomophthora species, and those with unbranched conidiophores as Empusa species. He also compounded the problem by setting up a third genus Lamia. Thaxter, 1888 also used three generic names. Olive, 1906 added a new dimension to the problem by regarding all types with uninucleate conidia as Entomophthora species and those with multinucleate conidia as Empusa species. Lakon, 1963 (written, 1939) also continued to use three generic names.

Couch, 1939 supported the usage of Empusa and Entomophthora. However, Steinhaus, 1949 observed that further research would probably show two distinct genera, with the reservation that the work done up to that time did not justify this. Macleod, 1956 followed the reasoning of Steinhaus and lumped all the species into one genus; unfortunately he chose to retain the name Empusa. 
Kevorkian, 1937, Hutchinson, 1962 and Hall and Bell, 1962 all concurred in the usage of the generic name Entomophthora to cover all species previously referred to under Entomophthora, Empusa, or Lamia. This practice is now generally accepted, e.g. MacLeod, 1963, and follows the strict application of the International Code of Botanical Nomenclature (Lanjouw et al, 1956).

This confusion over nomenclature resulted in the proliferation of synonyms. Gustafsson, 1965 collected 24 species of Entomophthora in Sweden, and he listed 45 synonyms for those species.

Batko, 1964 proposed a modern diagnosis of the genus Entomophthora Fresenius. non. Nowakowski.

The Entomophthorales are generally divided into two families. One is the Entomophthoraceae in. which the hyphae become septate and form hyphal bodies. The genera included are Entomophthora, Conidiobolus, Massospora, Completoria, Ancylistes, Strongwellsea, Entomophaga, Triplosporium and Tritirachium. The second is the Basidiobolaceae, where the septate hyphae do not form hyphal bodies. The family is monogeneric containing Basidiobolus only. Alexopoulos, 1962 distinguished between Entomophthora and Conidiobolus by the nature of zygospore formation. Srinivasan et al, 1964 regarded Entomophthora species as having determinate conidiophores, and Conidiobolus species as having indeterminate ones. Srinivasan and Thirumalachar, 1967 renamed $\underline{E}$. coronata as $\underline{C}$. coronata on these grounds. 
Studies on the cell walls of the Entomophthorales started with the work of Couch, 1939. He showed by histochemical means that cellulose made up the cell wall of $\underline{B}$. ranarum. This fact was confirmed by Harder, 1947 who also used histochemical means to determine this. Harder used the presence of cellulose as a basis for classifying Basidiobolus as one family. Couch, 1939 reported chitin in the cell walls of Entomophthora and Conidiobolus, and Nabel, 1939 reported the presence of chitin in the walls of Basidiobolus. In 1950 Frey used X-ray techniques, which are the most sensitive available for determining cellulose and chitin, to show the presence of chitin in the cell walls of Entomophthora and Basidiobolus and the absence of cellulose. The Zygomycetes are placed by Bartnicki-Garcia, 1968 in his chemical category (4), (see Table I), which comprises those fungi with cell walls predominantly made up of chitin and chitosan. This is based on work on the Mucorales, (BartnickiGarcia, 1962, Bartnicki-Garcia and Nickerson, 1962, BartnickiGarcia and Reyes, 1964, 1968a and 1968b).

\section{B. Outline of Research}

The order Entomophthorales in the class Zygomycetes has received much attention from biologists. However, basing the taxonomy of the group on strictly morphological characters has burdened the literature with synonyms. The order was chosen for study for several reasons. Firstly, this work was designed to determine whether a new criterion could be introduced into the 
system of classification to help to clarify some of the synonomy. Secondly, an attempt was made to find variations in carbohydrate composition in the vegetative cell wall that could be correlated with the variation in mycelial lipid composition found in the order by Tyrrell, 1966, 1967, and 1968. Thirdly, the carbohydrate composition of the vegetative cell wall was investigated to see how it compared with that in other orders of the Zygomycetes, and the other chemical categories of Bartnicki-Garcia's system.

To provide data for this study the qualitative and quantitative natures of the carbohydrates that make up the vegetative cell walls were determined. The fungi used in the present study were:

Entomophthora coronata (Costantin) Kevorkian E. exitialis Hall and Dunn E. thaxteriana (Petch) Hall and Bell E. virulenta Hall and Dunn E. musciae (Cohn) Fresenius Conidiobolus stromoidens Srinivasan and Thirumalachar Basisiobolus ranarum Eidam

This study is divided into three major sections. The first section is an outline of the testing of media to see if they would support good growth of the fungi under study. It was important to find a medium which would produce good vegetative growth only, in liquid shake culture. It was important to find a medium for growth which would comply with the requirements set 
forth by Tyrrell, 1969 who stated that "Every effort should be made to standardise culture conditions in order that valid comparisons between species can be made." The necessity for constant conditions can be illustrated by the work of Foster, 1949. He showed that the chitin content of fungal cells became greater with increasing acidity of the medium; the converse being true for increasing alkalinity. He observed that the chitin content was reduced at higher incubation temperatures, and that this rate of reduction was most rapid on alkaline media. The chitin content of fungal cells has also been shown to increase with the age of the cell. Also included in this section are details of the methods used to harvest the fungi, and to separate the cell walls from the cytoplasm. Chemical methods for bringing about this separation have been used for many years. The mechanical methods of separation are more recent, and were first applied to filamentous fungi by Kreger, 1954 .

The second section is the outline of a histochemical study made on both intact mycelium and isolated cell walls. This was designed to give some qualitative information on the nature of the polysaccharides present in the cell walls.

The third section contains details of techniques used for acid hydrolysis of cell wall fractions, the methods of purifying the hydrolysates by the use of ion-exchange resins, qualitative analysis of monosaccharides released by the hydrolysis with the aid of chromatographic techniques, and the quantitative analysis of the products of hydrolysis employing colourimetric 
methods.

A final section reports an experiment designed to determine the effects of changes in the carbon substrate of the media on the composition of the simple monosaccharides released from the wall by hydrolysis.

The significance of the results was considered in relation to the taxonomy of the group, and to the morphogenetic differences, particularly between the two families, Entomophthoraceae and Basidiobolaceae which comprise the order Entomophthorales. 


\section{TABLE I}

CELL WALL TAXONOMY OF FUNGI

(After Bartnicki-Garcia,1968)

Chemical Category

I. Cellulose-Glycogen

II. Cellulose-Glucan

III. Cellulose-Chitin

IV. Chitosan-Chitin

V. Chitin-Glucan

VI. Mannan-Glucan

VII. Mannan-Chitin
Taxonomic Group

Acrasiales

Oomycetes

Hyphochytridiomycetes

Zygomycetes

Chytridiomycetes

Ascomycetes

Basidiomycetes

Deuteromycetes

Saccharomycetaceae

Cryptococcaceae

Sporobolomycetaceae

Rhodotorulaceae

VIII. Polygalactosamine-Galactan Trichomycetes 
CHAPTER II - CULTURE METHODS AND SEPARATION TECHNIQUES

A. Materials and Methods

I. Sources of Fungi

The fungi used in this study were obtained from the American Type Culture Collection, with the exception of Entomophthora thaxteriana which was provided by Dr. E. Müller-Kögler.

II. Culture of Fungi

a. Maintenance of Stock Culturies

The fungi from the culture collections were maintained on slants of Sabouraud's dextrose agar containing $0.5 \%$ yeast extract. These stock cultures were routinely sub-cultured at three week intervals. Sabouraud's dextrose agar is the normal medium used for growing Entomophthora species. (Wolf, 1951, Hall and Dunn, 1958, and Gustafsson, 1965a)

b. Comparison of Media used for Mass Culture

For mass culturing it was desirable to have a medium which would support good growth of hyphal bodies free from conidia, azygospores or zygospores. Three liquid media were compared for their ability to meet these requirements in the shortest possible time. The media tested were those described by Gustafsson, 1965b, Jcilsson, 1968, and Rosinski and Campana, 1964 (After Beckman, 1956). The composition of the three media follows. 
Gustafsson, 1965b -

Three parts: $\mathrm{NaHPO}_{4} \cdot 7 \mathrm{H}_{2} \mathrm{O}$

$$
\begin{aligned}
& \mathrm{KH}_{2} \mathrm{PO}_{4} \\
& \mathrm{H}_{2} \mathrm{O}
\end{aligned}
$$

One part:

$$
\begin{aligned}
& \mathrm{MgSO}_{4} \cdot 7 \mathrm{H}_{2} \mathrm{O} \\
& \mathrm{FeCl}_{3} 1 \% \text { soln. }
\end{aligned}
$$$$
\text { Asparagine }
$$$$
\text { Yeast extract }
$$$$
\mathrm{H}_{2} \mathrm{O}
$$

One part:

$$
\begin{aligned}
& \text { Starch (Merck) } \\
& \mathrm{H}_{2} \mathrm{O}
\end{aligned}
$$

$\mathrm{pH} 6.8-7.0$

Jonsson, 1968 -

$$
\begin{gathered}
21.4 \mathrm{~g} \\
10.8 \mathrm{~g} \\
3000 \mathrm{ml} \\
2.5 \mathrm{~g} \\
3 \mathrm{drops} \\
4.2 \mathrm{~g} \\
0.5 \mathrm{~g} \\
1000 \mathrm{ml} \\
50 \mathrm{~g} \\
50 \mathrm{~g}
\end{gathered}
$$


Two litre flasks containing $250 \mathrm{ml}$ of medium were autoclaved at $121^{\circ} \mathrm{C}$ and 15 p.s.i. for 15 mins. After inoculation with portions of the colonies from the stock cultures, the experimental cultures were grown in a New Brunswick Psycrotherm for $48 \mathrm{hrs}$. at $25^{\circ} \mathrm{C}$, shaken at $120 \mathrm{r.p.m}$. (Some of the cultures grown in the early part of this study were shaken on a different piece of aparatus.) Temperature and $\mathrm{pH}$ conditions were based on the work of Gustafsson, 1965b. The species of fungi used to test the media were: E. coronata, E. virulenta, E. exitialis and E. muscae.

c. Determination of the Effect of Growth Temperature on Colony Morphology

Johnston et al, 1967 reported temperature dimorphism in an isolate of E. coronata from a mule phycomycosis. An attempt was made to determine the validity of this observation for that species, and to attempt to show differences in other species of Entomophthora under study. Using the stock cultures as a control group at $25^{\circ} \mathrm{C}$, a set of stock cultures were incubated at $37^{\circ} \mathrm{C}$ as an experimental group. The fungi used in this experiment were: E. coronata, E. exitialis, E. thaxteriana, and E. virulenta.

III. Separation of Cell Walls from Cytoplasm

The mass cultures, grown as outlined in section IIb above, were filtered through a Buchner funnel. and the mycelial pad which was collected was washed twice with distilled water. The mycelial pads then had to be treated in a manner that would ensure the maximum separation of the cytoplasmic and cell wall components 
of the mycelium. Three methods were compared to determine which was most efficient in achieving this separation. The first method was chemical in its action, the second and third were mechanical.

a. Chemical Separation (After Aronson and Machlis, 1959) The mycelial pads were boiled for 15 mins. in ten times their volume of $5 \%$ potassium hydroxide solution. The walls were then filtered and examined under a phase contrast microscope to determine if any cytoplasm remained. If any cytoplasm was detected the process was repeated until it was all removed. This normally required six periods of boiling. The filtered wall was then washed twice with boiling water, twice with $95 \%$ ethanol and twice with diethyl ether. The wall was then dried and stored, over silica gel in vacuo.

b. Mechanical Separation A (After Falcone and Nickerson, 1956) Mycelial pads were suspended in water. To this suspension was added $0.2 \mathrm{~mm}$ diameter glass beads until a thin paste was formed. This paste was then agitated in a Waring Blendor at low speed for 90 mins. The beads rapidly settled and the supernatant containing the mycelial fragments was decanted off. The walls were then spun down at $500 \mathrm{x} \mathrm{g}$ in an I.E.C. model HRI high speed refrigerated centrifuge for one minute, which left most of the cytoplasm in suspension. The supernatant was pipetted off and discarded. The walls were then washed successively with water, $8.5 \%$ sucrose, and $0.1 \mathrm{M}$ phosphate buffer, $\mathrm{pH} 7$, with centrifugation after each washing. This 
regime was repeated 50 times, followed by two final washings in water. The product was then dried and stored, in vacuo over silica gel.

c. Mechanical Separation B (after Aronson and Machlis, 1959) Mycelial pads were suspended in 25-30 $\mathrm{ml}$ of $1 \%$ phosphate buffer, $\mathrm{pH} 7$, in a: $50 \mathrm{ml}$ beaker. This was held so that the large probe of a M.S.E. ultrasonic disintegrator touched the surface of the suspension. A $250 \mathrm{ml}$ beaker containing iced water was then placed around the smaller beaker. The sonic disintegrator was then turned on and adjusted to its maximum power output. Sonication continued for 60 mins, the iced water being replaced when necessary. The sonicated mixture was then centrifuged at $500 \mathrm{x} \mathrm{g}$ for one minute at $0^{\circ} \mathrm{C}$. The pellet was then washed by suspension and centrifugation in the following solutions: $1 \mathscr{6}$ phosphate buffer, $\mathrm{pH} 7$ (three times), 1:I buffer:glycerol mixture (once), $0.1 \mathrm{M}$ sodium chloride (once), and water (five times). The product was then dried and stored, in vacuo over silica gel. Figures $1-18$ illustrate the various stages in the separation of the cell walls by this method.

All three preparations were examined by phase contrast microscopy before drying to ensure that the cytoplasm had been removed.

IV. Comparison of the Efficiency of the Separation Methods Before drying the samples from the three separation methods, samples were subjected to four histochemical tests to determine how much of the cytoplasm had been left behind in 


\section{FIGURES}

1. Entomophthora coronata, intact mycelium

2. E. coronata, sonicated mycelium

3. E. coronata, sonicated and washed mycelium

4. Entomophthora exitialis, intact mycelium

5. E. exitialis, sonicated mycelium

6. E. exitialis, sonicated and washed mycelium

7. Entomophthora thaxteriana, intact mycelium

8. E. thaxteriana, sonicated mycelium

9. E. thaxteriana, sonicated and washed mycelium

10. Entomophthora virulenta, intact mycelium

11. E. virulenta, sonicated mycelium

12. E. virulenta, sonicated and washed mycelium

13. Conidiobolus stromoideus, intact mycelium

14. C. stromoideus, sonicated mycelium

15. C. stromoideus, sonicated and washed mycelium

16. Basidiobolus ranarum, intact mycelium

17. B. ranarum, sonicated mycelium

18. B. 'ranarum, sonicated and washed mycelium 

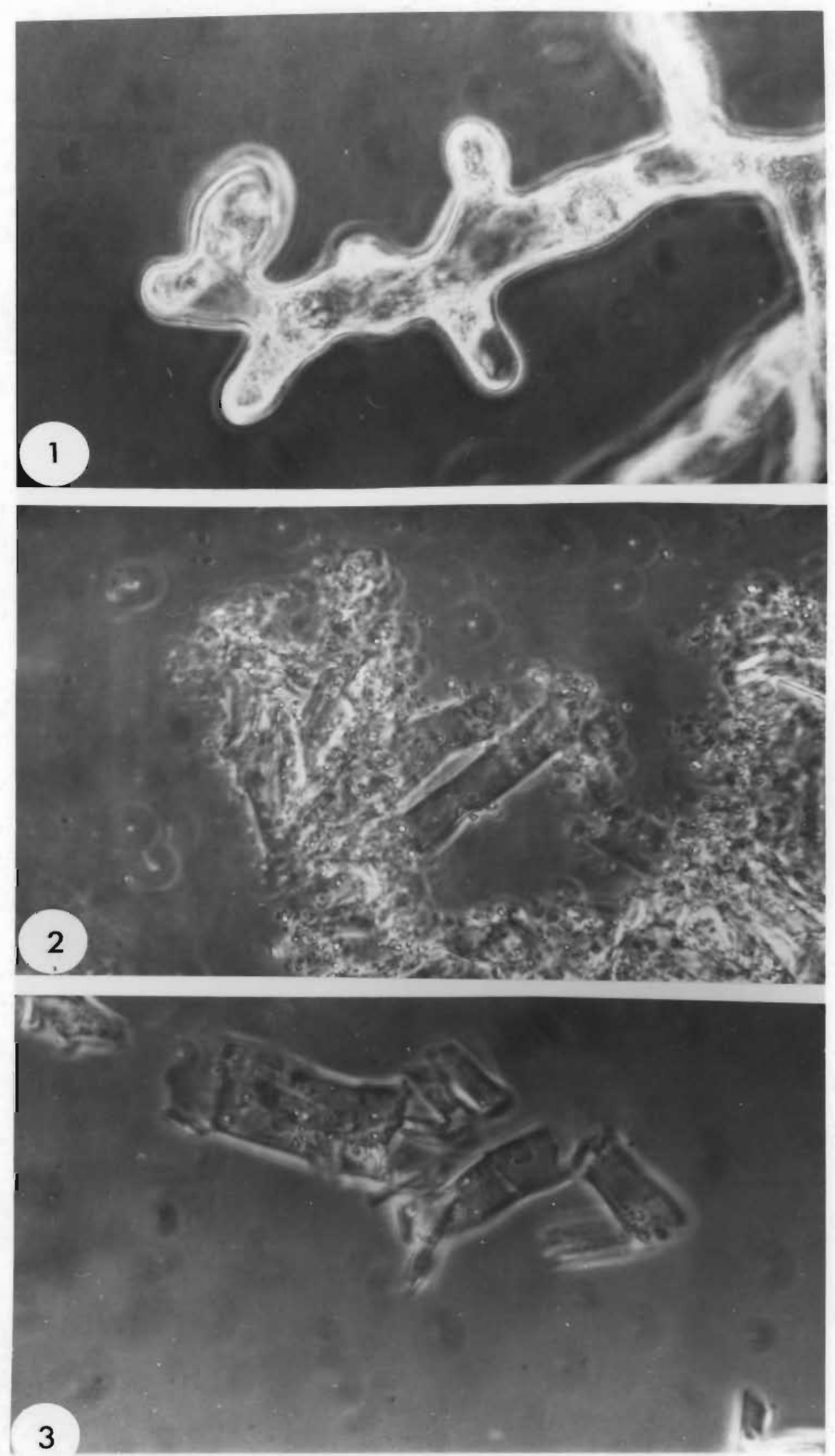

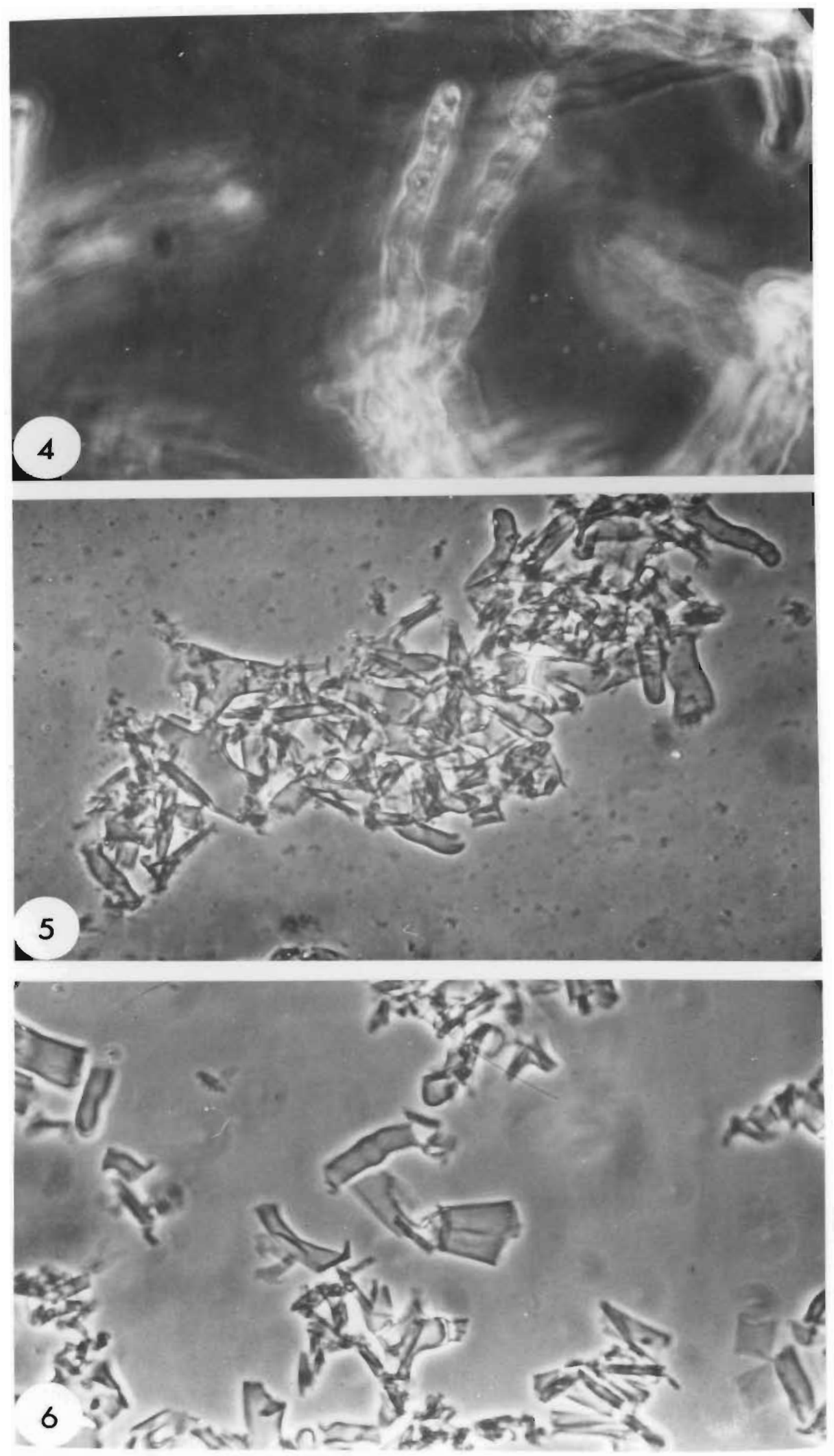


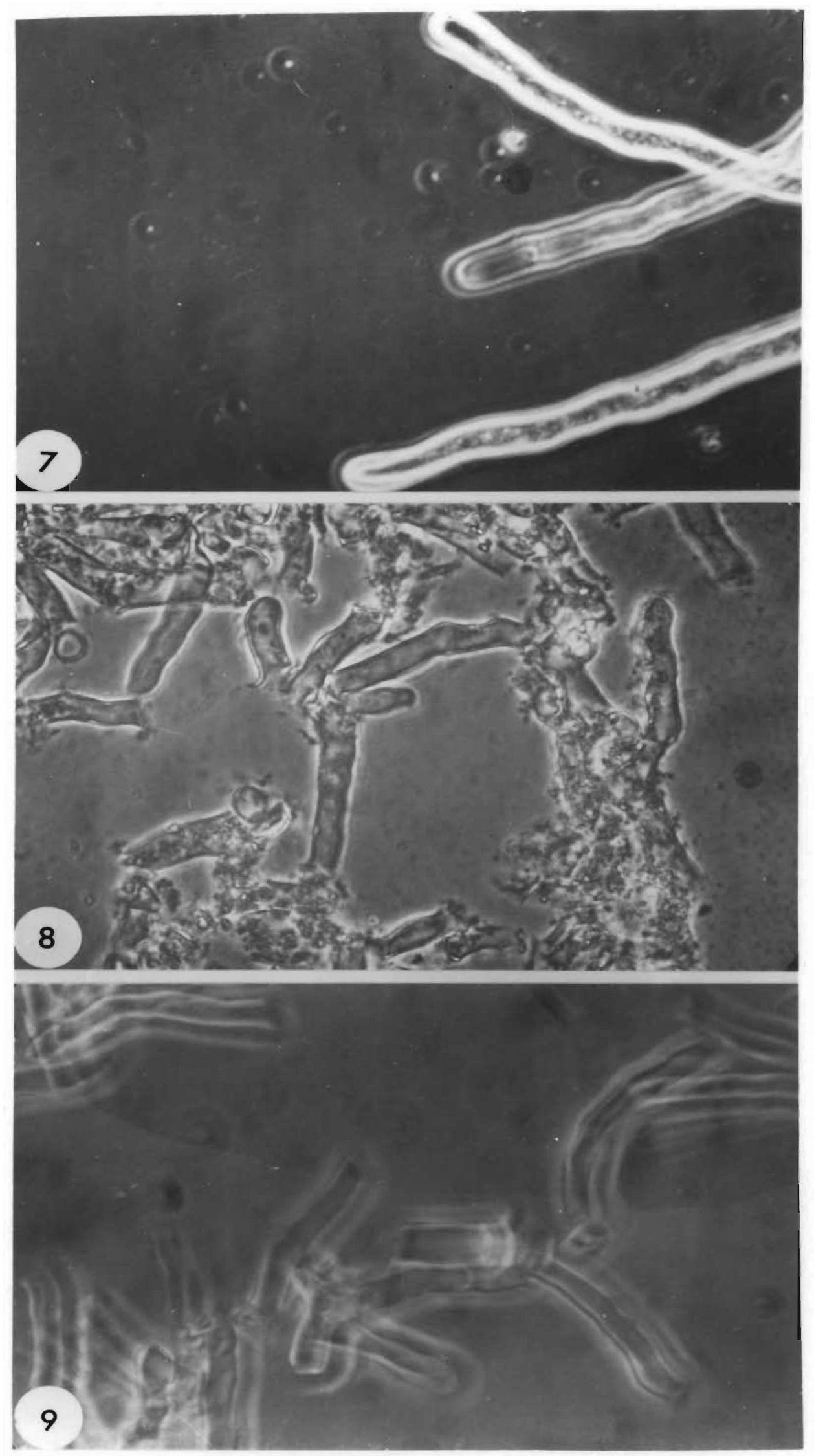



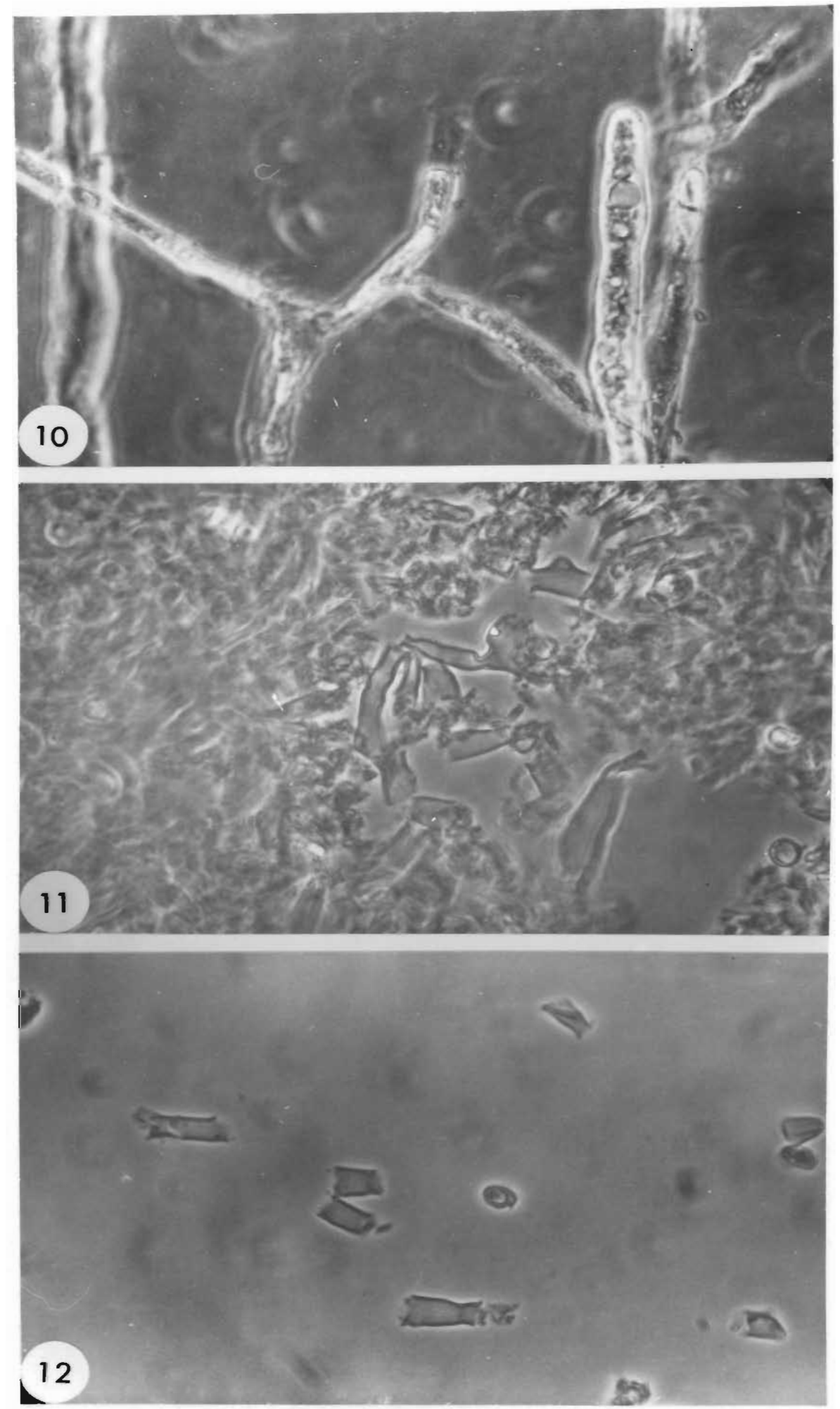

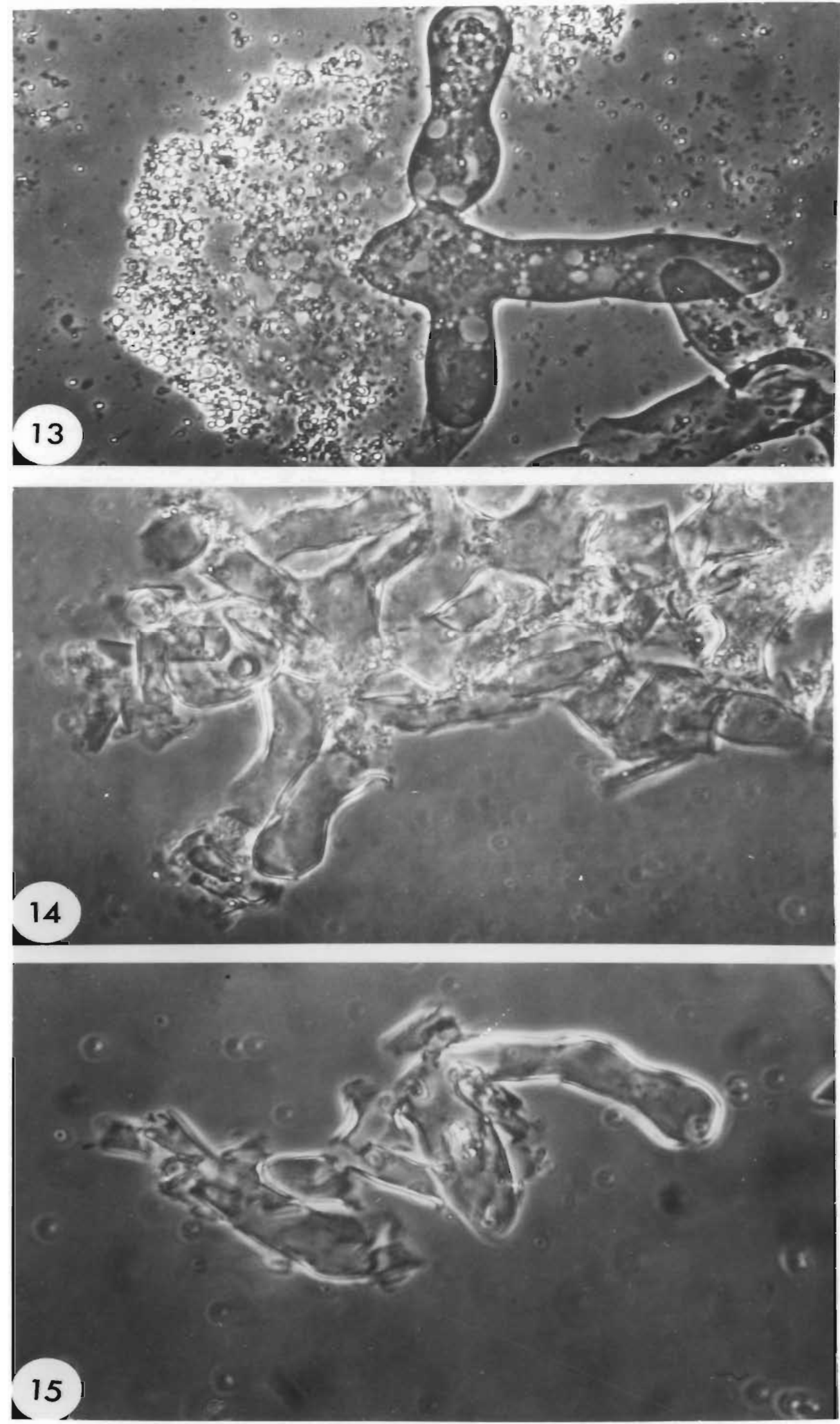

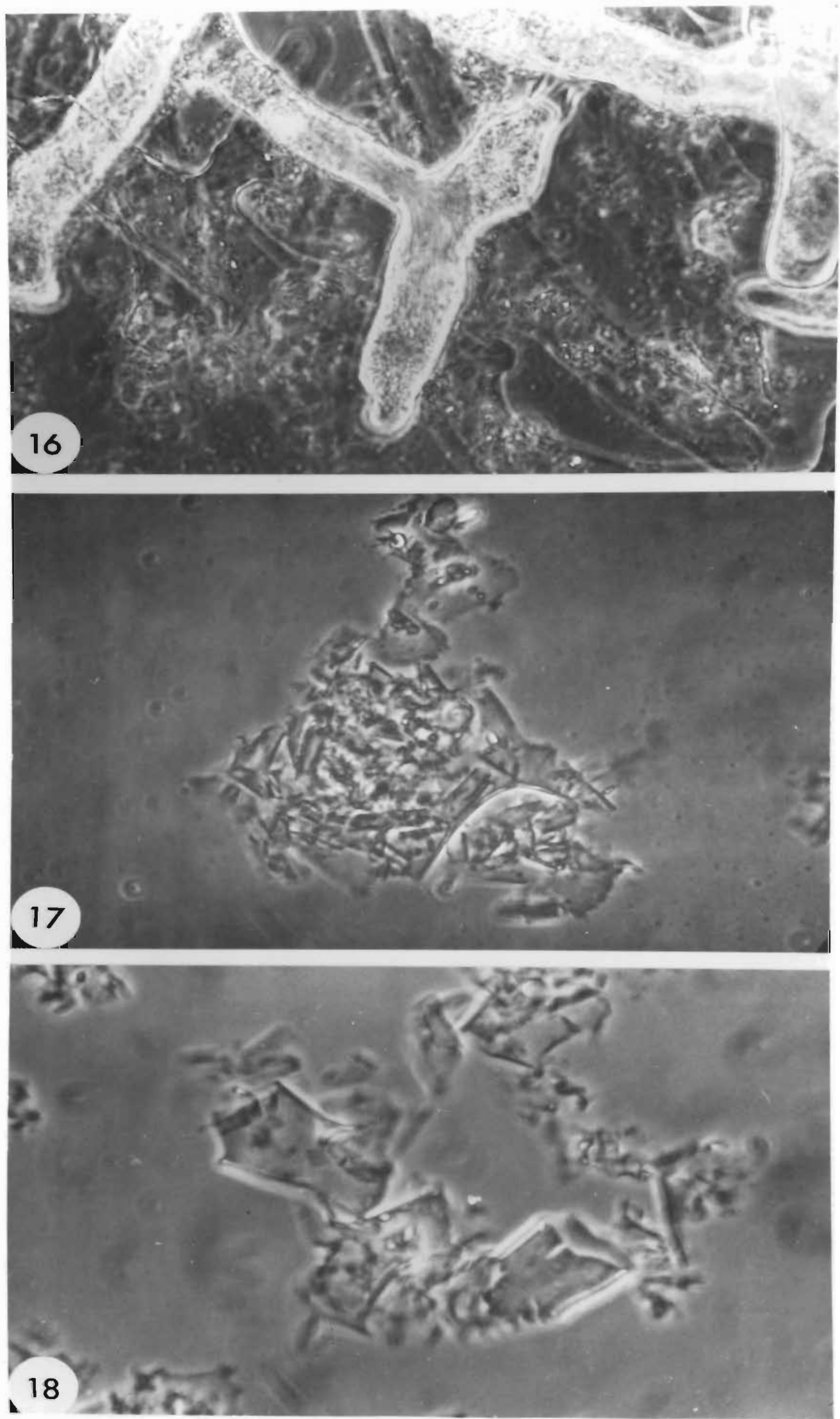
the sample. The four tests were:

a. Periodic Acid-Schiff's Test for Carbohydrates (Jensen, 1962)

b. Ninhydrin-Schiff's Test for Proteins (Jensen, 1962)

c. Mercuric Bromophenol Blue Test for Proteins (Mazia et al, 196.2)

d. Sudan IV Test for Lipids (Jensen, 1962)

In all cases the moist wall material was smeared onto a slide and air dried. The slides could then be immersed in the reagents in coplin jars. For some of the tests it was necessary to cover the specimen on the slide with a film of celloidin to prevent loss. The film was applied by the method of Kanwar, 1967. The slides were smeared with the cell wall samples, dipped successively in $100 \%$ ethanol, $0.5 \%$ celloidin in 50:50 ethanol:diethyl ether for five minutes, $90 \%$ ethanol, and stained by the appropriate technique.

a. Periodic Acid-Schiff's Test

Slides were immersed in the following series of reagents for the times specified.

(1) $0.5 \%$ periodic acid, 15 mins.

(2) Running tap water, 10 mins.

(3) Schiff's reagent (Longley, 1952) 15 mins.

(4) Water rinse

(5) $2 \%$ sodium metabisulphite, 2 mins.

(6) Running tap water, 10 mins.

(7) Mounted in glycerol 
b. Ninhydrin-Schiff's Test

(1) 0.58 ninhydrin in $100 \%$ ethanol at $37^{\circ} \mathrm{C}, 24 \mathrm{hrs}$.

(2) Ethanol $100 \%$ rinse (repeat)

(3) Water rinse

(4) Schiff's reagent (Longley, 1952) 15 mins.

(5) Water rinse

(6) 28 sodium metabisulphite, 2 mins.

(7) Running tap water, 20 mins.

(8) Mounted in glycerol

As a control for this test some slides were first acetylated for 12 hours in a $10 \%$ solution of acetic anhydride in pyridine at $25^{\circ} \mathrm{C}$ and then subjected to the ninhydrin-Schiff's test.

c. Mercuric Bromophenol Blue Test

(1) Mercuric bromophenol blue (10 g mercuric chloride and $100 \mathrm{mg}$ bromophenol blue in $100 \mathrm{ml}$ water).

(2) $0.5 \%$ acetic acid, 20 mins.

(3) 18 phosphate buffer $\mathrm{pH} 7,3$ mins.

(4) Mounted in glycerol

d. Sudain IV

(1) $50 \%$ ethanol, 2 mins.

(2) Sudan IV (saturated and filtered solution in $70 \%$

ethanol), 20 mins.

(3) $50 \%$ ethanol, differentiate for up to two mins.

(4) Mounted in glycerol 


\section{B. Results}

I. Culture

a. Comparison of Media used for Mass Culture

The yields of the three media were evaluated visually on the basis of the thickness of the mycelial pad in the filter. All three media satisfied the requirements of producing only mycelial growth. The results of the experiment after 48 hours growth are depicted in Table II.

b. The Effect of Growth Temperiature on Colony Morphology

The fungi grown at $37^{\circ} \mathrm{C}$ showed no change in the morphology of their colonies as compared with those at $25^{\circ} \mathrm{C}$. The size of the hyphal bodies was unaffected, and there was no sporulation at either temperature.

\section{Separation}

All three separation methods produced satisfactory cell wall specimens. The chemical technique produced the cleanest cell wall when observed by phase contrast microscopy. The two mechanical methods yielded cell walls with traces of contamination from residual cytoplasm. The mechanical procedure of Falcone and Nickerson, 1962 produced wall specimens which had fragments of glass beads associated with them. The largest cell wall specimens were produced by the mechanical technique of Aronson and Machlis, 1959. 
TABLE II

COMPARISON OF MEDIA USED FOR MASS CULTURE

\begin{tabular}{|c|c|c|c|}
\hline $\begin{array}{l}\text { Fungus } \\
\text { Medium }\end{array}$ & Gustafsson & Jonsson & $\begin{array}{l}\text { Rosinski } \\
\text { and } \\
\text { Campana }\end{array}$ \\
\hline E. coronata & $+t+$ & $++t$ & +++ \\
\hline E. exitialis & + & ++ & $+t+$ \\
\hline E. muscae & - & - & - \\
\hline E. virulenta & ++ & $+t$ & ++ \\
\hline
\end{tabular}

$\begin{aligned}+++ & \text { Good growth } \\ ++ & \text { Fair growth } \\ + & \text { Poor growth } \\ + & \text { Little or no growth }\end{aligned}$


III. Comparison of the Efficiency of the Separation Methods The results of the histochemical tests are given in Table III.

The results of the culture and separation studies are important as they provide the basis for the rest of the study. The choice of Rosinski and Campana's medium, a growth temperature of $25^{\circ} \mathrm{C}$ and Aronson and Machlis' mechanical separation technique, ensure that all later work can be done against this well defined set of conditions. 
TABLE III

\section{HISTOCHEMICAL TESTS ON EFFICIENCY OF SEPARATION METHODS}

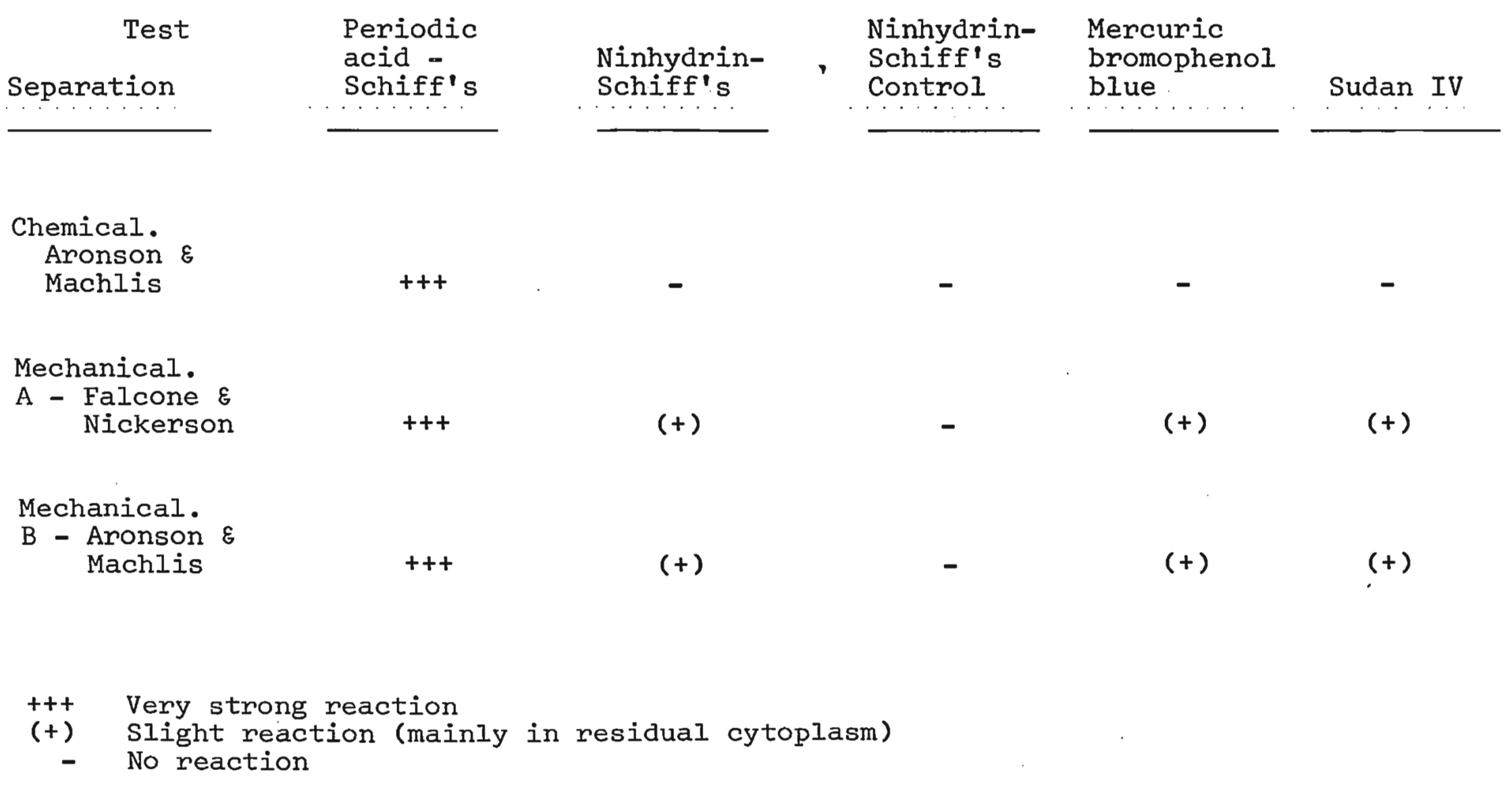


CHAPTER III - HISTOCHEMISTRY

A. Materials and Methods

To obtain preliminary qualitative information about the nature of the polysaccharides present in the cell wall a histochemical survey was carried out. This also allowed some predictions to be made on the nature of the monosaccharides which would be released from the wall by later hydrolysis.

Tests were first carried out on intact mycelium and later on wall fractions separated by the Aronson and Machlis, 1959 mechanical technique. The sequence of tests carried out on the separated wall is illustrated in Table IV.

I. Tests on Intact Mycelium

a. Celiulose Test, $\mathrm{IKI}_{-} \mathrm{H}_{2} \mathrm{SO}_{4}$ (Jensen, 1962)

(1) Fresh samples of the fungi were mounted in IKI. (Two grams of potassium iodide in $100 \mathrm{ml}$ of water, followed by $0.2 \mathrm{~g}$ of iodine) for $15 \mathrm{mins}$.

(2) Cover glasses were placed over the specimens.

(3) Drops of $65 \%$ sulphuric acid were placed at one end of each cover slip and allowed to diffuse under them.

As a control a piece of filter paper was subjected to the test, with the production of a positive dark blue colour.

b. Cellulose Test, Zinc-Chlor Iodide (Jensen, 1962)

(1) Fresh samples of the fungi were mounted in zincchlor iodide. $(50 \mathrm{~g}$ zinc chloride, $16 \mathrm{~g}$ potassium iodide in $17 \mathrm{ml}$ water. Excess iodine was added and the solution was kept for two days in the dark before use.) 
As a control a piece of filter paper was used which gave a blue positive reaction. c. Pectin Test, Hydroxylamine-Ferric Chloride (Jensen, 1962)

(1) Fresh specimens of the test fungi were mounted on slides.

(2) Fresh hydroxylamine was added for five minutes. (prepared by mixing equal volumes of sodium hydroxide $[14 \mathrm{~g}$ in $100 \mathrm{ml} 60 \%$ ethanol] and hydroxylamine hydrochloride [14 $\mathrm{g}$ in $100 \mathrm{ml} 60 \%$ ethanol]).

(3) To the slides were added equal volumes of a solution made from one part concentrated hydrochloric acid and two parts $95 \%$ ethanol.

As a control a leaf epidermal strip was used which gave a positive red colour in the middle lamellae of the cells.

II. Tests on Separated Cell Wall

a. Chitosan Test (Roelofsen and Hoette, 1951)

Cell wall material was mounted in IKI-I\% $\mathrm{H}_{2} \mathrm{SO}_{4}$ (made by adding $2 \mathrm{~g}$ potassium iodide to $100 \mathrm{ml} 1 \%$ sulphuric acid, then adding $0.2 \mathrm{~g}$ of iodine). A control was set up by washing the wall material in $2 \%$ acetic acid followed by two washes in boiling water to remove any chitosan (Jensen, 1962). Only a purple colour is regarded as a positive reaction, a brown colour is regarded as negative.

b. Alternative Chitosan Test (Kreger, 1954)

Cell wall material was extracted in boiling $2 \%$ hydrochloric acid for two hours. The residue was removed by centri- 
fugation and the supernatant was neutralised with 4.5\% potassium hydroxide. Any precipitate was centrifuged off and subjected to test a. A similar control to test a was used. c. Cellulose Test (Jensen, 1962)

The cell wall was mounted in IKI and $65 \%$ sulphuric acid was run under the cover slip. A blue colour would be positive.

\section{d. Cellulose Birifringence Test (Fuller, 1960)}

Cell wall material was examined with polarized light. Birifringent areas would indicate that cellulose was present. e. Maninain Test (Gorin and Spencer, 1968)

Cell wall material was treated with $4.5 \%$ potassium hydroxide at $80^{\circ} \mathrm{C}$, for 30 mins. The residue was centrifuged off and the supernatant treated with Fehlings solution. A precipitate would indicate mannans were present.

f. Chitin Solubility Test (Roelofsen and Hoette, 1951)

Cell wall material was extracted in $5 \%$ sodium hypochlorite for 12 hours, so any residue would contain material other than chitin.

g. Chitin Test (Roelofsen and Hoette, 1951)

Cell wall was autoclaved with $60 \%$ potassium hydroxide at $121^{\circ} \mathrm{C}$ and $15 \mathrm{p} . \mathrm{s.}$. for three hours. The chitosan test a was then applied. As a control the residue after autoclaving was washed once with $2 \%$ acetic acid and twice with boiling water to remove chitosan. The chitosan test was then applied. The 


\section{TABLE IV}

\section{SEQUENCE OF TESTS ON ISOLATED CELL WALLS}

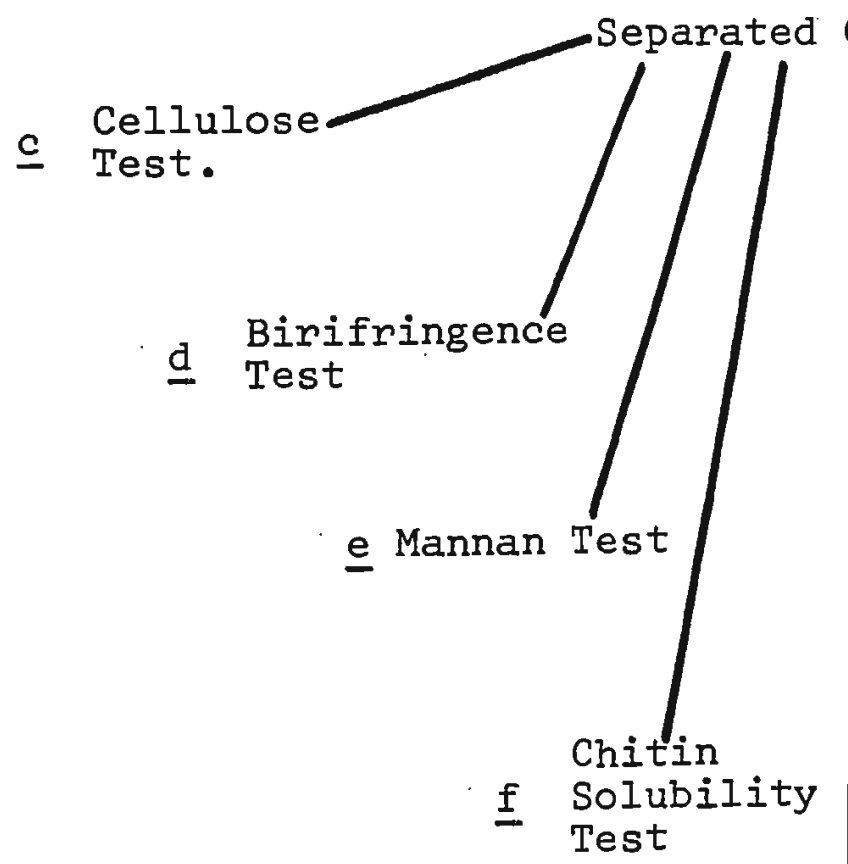

$\left.\right|_{\mid} ^{\text {CeIl }}$

bI Solubility

Test

Control

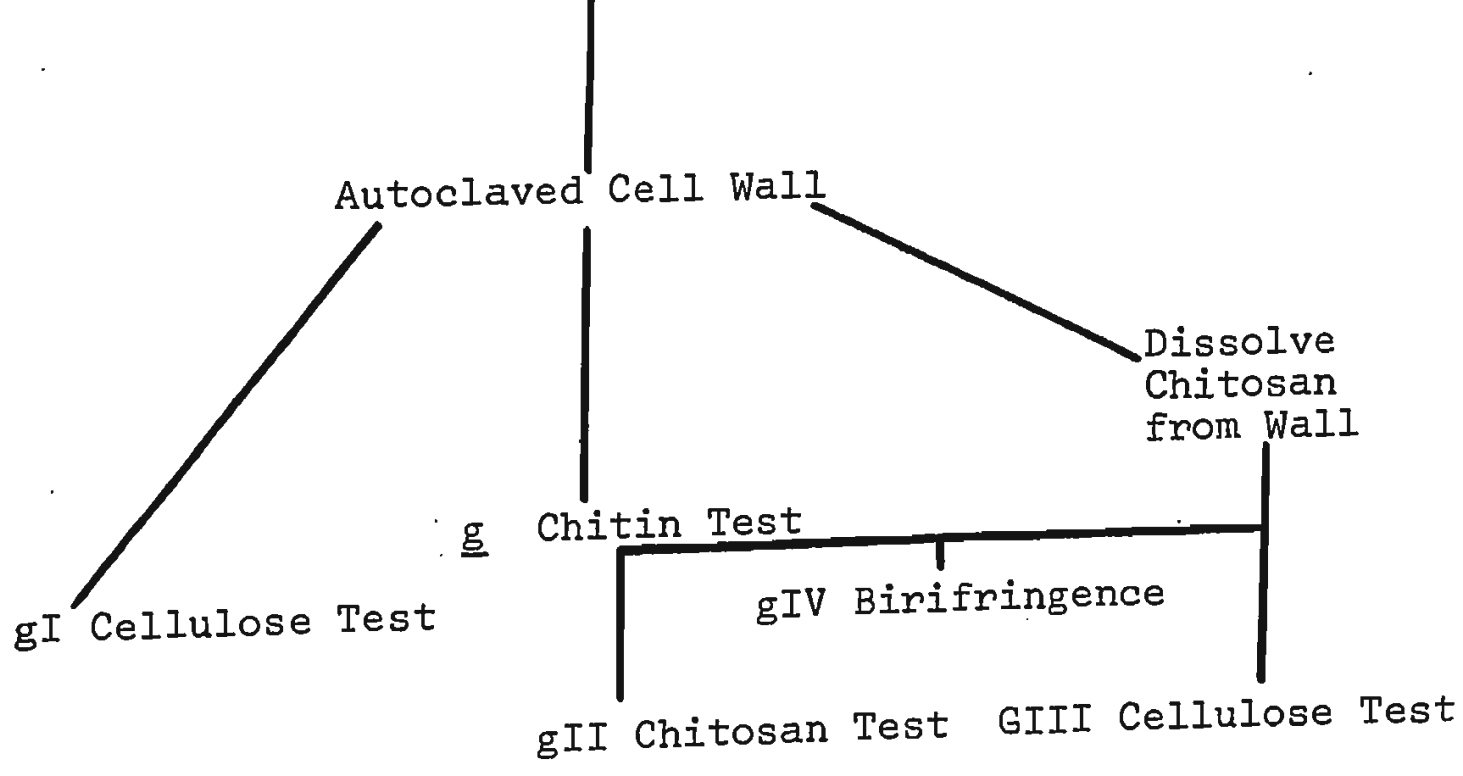


cellulose test $\underline{c}$ was also applied to material after autoclaving. Both the cellulose test and the cellulose birifringence test were applied to cell wall material after autoclaving followed by treatment with $2 \%$ acetic acid.

The results of the above experiments were regarded as tentative and further experiments were carried out to obtain confirmatory and additional information.

B. Results

I. Tests on Intact Mycelium

The results of the histochemical tests on intact fungal mycelium are given in Table $\mathrm{V}$.

II. Tests on Separated Celil Wall

The results of the histochemical tests on the separated fungal mycelium are given in Table VI. 
TABLE V

HISTOCHEMICAL TESTS ON INTACT MYCELIUM

Fungus
Test
E.c. E.e. E.t. E.v. C.s. B.r. Control

a IKI -

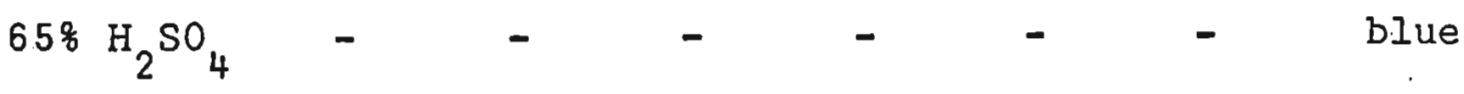

b Zinc-

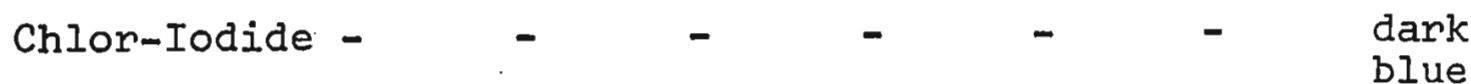

c Hydroxy- pink pink pink pink pink pink red lamine $\mathrm{FeCl}_{3}$

- Negative reaction 
TABLE VI

HISTOCHEMICAL TESTS ON SEPARATED CELL WALL

$\begin{array}{lccccccc}\text { Test } & \text { E.c. } & \text { E.e. } & \text { E.t. } & \text { E.v. } & \text { C.s. } & \text { B.r. } \\ \text { a } & \text { yellow } & \text { yellow } & \text { yellow } & \text { yellow yellow } & \text { red-brown } \\ \text { aI } & \text { yellow } & \text { yellow } & \text { yellow } & \text { yellow } & \text { yellow } & \text { red-brow. } \\ \text { b } & \text { no ppt. } & \text { no ppt. } & \text { no ppt. } & \text { no ppt. } & \text { no ppt. } & \text { no ppt. } \\ \text { bI } & \text { no ppt. } & \text { no ppt. } & \text { no ppt. } & \text { no ppt. } & \text { no ppt. } & \text { no ppt. } \\ \text { c } & - & - & - & - & - & - \\ \text { d } & - & - & - & - & - & - \\ \text { e } & \text { no ppt. } & \text { no ppt. } & \text { no ppt. } & \text { no ppt. } & \text { no ppt. } & \text { no ppt. } \\ \text { f } & \text { Dissolves } & \text { Dissolves } & \text { Dissolves Dissolves Dissolves } & \text { Dissolves } \\ \text { g } & \text { purple } & \text { purple } & \text { purple } & \text { purple } & \text { purple } & \text { purple } \\ \text { gI } & - & - & - & - & - & - \\ \text { gII } & - & - & - & - & - & - \\ \text { gIII } & - & - & - & - & - & - \\ \text { gIV } & - & - & - & - & - & -\end{array}$

- Negative reaction

no ppt. No precipitate 
CHAPTER IV - HYDROLYSIS OF WALL SAMPLES, PURIFICATION AND ANALYSIS

A. Materials and Methods

Following the separation of the cell walls, methods had to be employed to break down the component polysaccharides of the wall into monosaccharides which could be subjected to qualitative and quantitative analysis. Three different hydrolysis techniques were chosen to hydrolyse three different polymers which could be present in the cell walls. One technique was to ensure the hydrolysis of chitin and chitosan into amino sugar monomers. A second was designed to release simple monosaccharides from any homo-or heteropolysaccharides of simple sugars. The third was to bring about release of unonic acids which may be present as polyuronides (pectins). . Having released the monomers the samples were purified to produce material suitable for analysis.

I. Techrigues of Hydrolysis

a. To Release Amino Sugar Monomers (Bartnicki-Garcia and Nickerson, 1962)

Approximately $0.02 \mathrm{~g}$ quantities of dry cell wall samples were weighed out accurately in glass tubes. The tubes were drawn out to produce a long neck in an air-propane flame. Two $\mathrm{ml}$ of $6 \mathrm{~N}$ hydrochloric acid were then added to each tube and care was taken to ensure all the wall fragments were wetted. The tubes were then carefully sealed. They were then heated in an oven at $105^{\circ} \mathrm{C}$, for eight hours. On cooling the tops of the tubes were broken and the contents were allowed to dry in vacuo over pellets of potassium hydroxide. 
b. To Release Simple Monosaccharides (Bartnicki-Garcia and Nickerson, 1962)

Approximately $0.02 \mathrm{~g}$ quantities of a dry cell wall sample were again weighed out in glass tubes which were then partially drawn out. Two $m$ l of IN sulphuric acid were then added to each tube. The tubes were then sealed with care and were placed in an oven at $105^{\circ} \mathrm{C}$ for six hours. After cooling the tops of the tubes were broken.

c. To Release Uronic Acid Monomers (Gancedo et al, 1966) Again $0.02 \mathrm{~g}$ quantities of dry cell wall were weighed out in glass tubes which were then partially drawn out. Two ml of $3 \%$ nitric acid were then added and the tubes were sealed. Heating took place at $105^{\circ} \mathrm{C}$ for four hours in an oven. The tubes were then broken and the contents were left to dry over potassium hydroxide pellets in vacuo.

d. To Release Monomers for the Anthrone Test

Approximately $0.02 \mathrm{~g}$ quantities of dry cell wall samples were weighed out accurately and sealed in glass tubes with two $\mathrm{ml}$ of $1 \mathrm{~N}$ sulphuric acid. The tubes were heated at $105^{\circ} \mathrm{C}$ for six hours. The tubes were then broken at the tip and the contents dried over potassium hydroxide pellets in vacuo.

II. Techniques of Purifying Hydrolysates

a. To purify Amino Sugar Monomers

The dry samples from the hydrolysis procedure were dissolved in two $\mathrm{ml}$ of warm water. The solution was poured into an ion exchange column containing Bio Rad AG50W-X8, 50-100 mesh 
resin. The hydrolysis tube was washed with water and the washings were added to the column. (Prion to the addition of the test solution the column had been washed with $2 \mathrm{~N}$ hydrochloric acid and then water, the column was normally stored with $2 \mathrm{~N}$ hydrochloric acid covering the resin.) The hydrolysate was washed through the column with water leaving amino sugar ions bound to the resin. The amino sugar ions were washed off the column with $2 \mathrm{~N}$ hydrochloric acid. This fraction was collected in a flask and evaporated to dryness by a Buchler Flash Evaporator. The residue in the flask was then dissolved in $128 \mathrm{ml}$ of water. The column was then regenerated by washing with $2 \mathrm{~N}$ sodium hydroxide, $2 \mathrm{~N}$ hydrochloric acid and water.

b. To Purify Simple Monosaccharides

For each cell wall sample three hydrolysates were pooled for further treatment. The three samples were pooled in a $50 \mathrm{ml}$ beaker, the tubes were washed, and the washings were added to the beaker. The hydrolysates were then neutralised by the addition of barium hydroxide, neutrality being determined by a Corning pH meter. The neutralised hydrolysates were then centrifuged to remove barium sulphate. The supernatant and the washings from the barium sulphate residue were then deionised in an ion exchange column containing equivalent weights of Bio Rad AG50W-X8, 50-100 mesh resin and Bio Rad AGI-X8, 50-100 mesh resin. The fluid wasked through the column was retained for analysis. The fluid was collected in a flask and evaporated to dryness by a Buchler Flash Evaporator. The residue was then taken up in six $\mathrm{ml}$ of water. 


\section{c. To Purify Uronic Acid Monomers (Percheron, 1967)}

The dry samples from the hydrolysis treatment were dissolved in warm water and added to an ion exchange eolumn along with the washings of the hydrolysis tubes. The column contained Bio Rad AG50W-X8, 50-100 mesh resin which had been washed in $0.5 \mathrm{~N}$ formic acid, then water. (The resin was normally stored covered with $0.5 \mathrm{~N}$ formic acid.) The hydrolysate was washed over the column with water. The uronic acid ions were then eluted from the column by washing with $0.5 \mathrm{~N}$ formic acid. The eluted fluid was collected in a flask and dried in a Buchler Flash evaporator. The residue was taken up in $30 \mathrm{ml}$ of water. The column was regenerated by washing with $0.5 \mathrm{~N}$ sodium hydroxide, $0.5 \mathrm{~N}$ formic acid and water respectively.

d. To Purify Monomers for the Anthrone: Test

The dry samples from the hydrolysis treatment were treated in a similar manner to the hydrolysates containing simple monosaccharides. The purified solution from the column was dried and then taken up in six ml of water.

III. Techiligues for Analysing Purified Cell Wall Hydrolysates The four purified hydrolysate preparations were subjected to qualitative and quantitative analysis to determine their sugar composition.

a. Qualitative Analysis

\section{(1) For Amino Sugars}

Amino sugars were identified in the samples by descending paper chromatography. Onto sheets of Whatman No. 1 paper, 
$57 \times 23 \mathrm{cms}$, were spotted out 50 plitre samples of test solution. Also placed on the start line were 10 plitre spots of a $5 \mathrm{~g} /$ litre solution of glucosamine. The papers were suspended from a trough containing a 25:6:25 v/v n-butanol:acetic acid:water solvent, (Bartnicki-Garcia and Nickerson, 1962). The solvent was allowed to run for 18 hours. The sheets were then taken down, air dried, and dipped in aniline hydrogen phthalate (prepared according to Stahl, 1965 by mixing $0.93 \mathrm{~g}$ analine and $1.66 \mathrm{~g}$ o-phthalic acid in $100 \mathrm{ml}$ of water saturated n-butanol). The sheets were air dried and then heated for 10 minutes at $105^{\circ} \mathrm{C}$.

(2) For Simple Monosaccharides

Simple monosaccharides were also identified by descending paper chromatography on Whatman No. 1 paper, $57 \mathrm{x}$ 23 cms. On the start line were placed 50 plitre samples of the test solutions (for Conidiobolus and Basidiobolus $200 \mu$ itre samples were nedessary). Also on the start line were placed $10 \mu$ litre samples of $5 \mathrm{~g} / \mathrm{litre}$ solutions of $\cdots$ known sugars. The papers were suspended from troughs containing a $6: 4: 3 \mathrm{v} / \mathrm{v} \mathrm{n}-$ butanol:pyridine:water solvent. (Bartnicki-Garcia and Nickerson, 1962). The solvent ran for 18 hours. The paper was air dried, dipped in aniline hydrogen phthalate, air dried, and heated for 10 minutes at $105 \mathrm{C}$.

(3) For Uronic Acids

Descending paper chromatography was again used. On the start line were placed $200 \mu$ iitres of unknowns alongside 
10 plitre samples of a $5 \mathrm{~g} /$ litre solution of D-glucuronolactone. The papers, Whatman No. I, $57 \times 23 \mathrm{cms}$, were hung from troughs containing $2: 1: 2 \mathrm{v} / \mathrm{v}$ ethyl acetate:acetic acid:water solvent. The solvent ran for 18 hours. The papers were then air dried, dipped in reagent, air dried and heated for five minutes at $80^{\circ} \mathrm{C}$. The reagent was: diphenylamine, $2 \%$ in ethanol: aniline, 2\% in ethanol: phosphoric acid v/v 5:5:1 (Gancedo et al, 1966). b. Quantitative Analysis

\section{(1) For Amino Sugars}

Total amino sugar composition was determined by a modification of the Elson and Morgan Technique (Tracey, 1955). One mI samples of the purified amino sugar monomers test solutions were placed in test tubes. To each tube was added one drop of $0.5 \%$ phenolphthalein in ethanol. Next, $4 \mathrm{~N}$ sodium hydroxide was added drop by drop to the tubes until the phenolphthalein. just turned pink. To the tubes was then added $0.5 \mathrm{~N}$ hydrochloric acid drop by drop until the solutions just became colourless. This ensured the test solutions were neutral. A series of one $\mathrm{ml}$ standards was also set up containing $5,10,15$, $20,25,30,35$ and $40 \mu \mathrm{g} / \mathrm{ml}$ of glucosamine respectively. To the standards was added one drop of the phenolphthalein reagent, and a number of drops of $4 \mathrm{~N}$ sodium chloride equal to the number of drops of alkali plus acid that had been added to the test solutions. This ensured that the standards were of equal ionic strength and composition to the test solutions..

To each tube of standard and test solution was added one $\mathrm{ml}$ of acetyl acetone reagent (prepared by refluxing actyl 
acetone $[2,4$, pentanedione $]$ at $138-140^{\circ} \mathrm{C}$, and collecting the colourless fraction; this was then mixed with $1.5 \mathrm{~N}$ sodium carbonate, $1: 25 \mathrm{v} / \mathrm{v}$ acetyl acetone: sodium carbonated The tubes were then heated at $89-92^{\circ} \mathrm{C}$ for 45 minutes. The tubes were cooled quickly and to each one was added $2.5 \mathrm{ml} 100 \%$ ethanol and one ml Ehrlichs' reagent. (The latter reagent is prepared by adding $1.6 \mathrm{~g}$ p-dimethylaminobenzaldehyde to $60 \mathrm{ml}$ of a 1:1 mixture of 100\% ethanol: concentrated hydrochloric acid.) The tubes were shaken during these additions. The tubes were allowed to stand at room temperature for 15 minutes and then the absorption of their contents was measured at $530 \mathrm{~m} \mu$ in a Beckman DKIlB ratio recording spectrophotometer against a blank which contained no amino sugar. With each fresh batch of samples a new series of standards was made up to ensure similarity of treatment conditions.

(2) For Simple Monosaccharides

Individual. monosaccharides were determined quantitatively by the method of Wilson, 1959. Samples of purified hydrolysate were spotted out onto the start line of a sheet of Whatman No. 1 paper, $57 \times 23 \mathrm{cms}$. Samples were of $50 \mu$ litres for the Entomophthora species. The samples were streaked out over one inch of the start line. Also spotted out were $1,2,4,6,8$, and $10 \mu l i t r e$ spots of a known glucose solution containing 5, 10, 20, 30,40 and $50 \mu g$ of glucose respectively. The papers were all run in a descending manner for 18 hours in the n-butanol:pyridine: water solvent. The sheets were air dried, dipped in aniline 
hydrogen phthalate, ain dried and heated at $105^{\circ} \mathrm{C}$ for 10 mins. Areas of paper $5 \frac{1}{1} \times 2 \frac{1}{2} \mathrm{cms}$, containing the brown sugar spots were cut out, also cut out were equal areas of paper with no spots to serve as controls. The pieces of paper were cut up into test tubes and shaken in $5 \mathrm{ml}$ of $0.75 \mathrm{~N}$ hydrochloric acid in $80 \%$ ethanol for one hour. The eluates were then decanted off, and their absorptions were read at $390 \mathrm{m \mu}$ in a Beckman DKIIB spectrophotometer using the paper without spots as blanks.

(3) For Uronic Acids

This determination utilised the method of Bitter and Muir, 1962. First $5 \mathrm{ml}$ of acid reagent containing $0.025 \mathrm{M}$ sodium tetraborate decahydrate in concentrated sulphuric acid) was added to a tube and cooled in iced water. One $\mathrm{ml}$ of standard or test solution was then layered on to the acid and mixed with it, with cooling. The mixture was then heated for 10 minutes in a bath of boiling water. The tubes were cooled to room temperature ard $0.2 \mathrm{ml}$ of carbazole reagent was added. (Carbazole reagent is $0.125 \%$ carbazole in $100 \%$ ethanol.) The tubes were shaken, then heated for 15 minutes in a bath of boiling water. On cooling to room temperature the absorption was measured at $530 \mathrm{m \mu}$ in a Beckman DKIIB spectrophotometer using a blank containing no uronic acid. Standards were made up containing 5, $10,15,20,25$ and $30 \mu \mathrm{g}$ of glucuronolactone/ml.

(4) For Total Non-Nitrogenous Sugar

This determination was made by the Chung and Nickerson, 1954 variation of the Anthrone test. From the solution to be tested were taken $0.05 \mathrm{ml}$ samples, and these were diluted to one 
ml. Standards were made up containing $10,25,50,75,100$, 125,150 , and $200 \mu \mathrm{g}$ of glucose $/ \mathrm{ml}$. With cooling in ice water $5 \mathrm{ml}$ of Anthrone reagent $(0.2 \mathrm{~g}$ Anthrone in $100 \mathrm{ml} 3: 1$ sulphuric acid:water) were added to the tubes containing the test solutions and standards. The tubes were boiled for 10 minutes then cooled rapidly in iced water. The absorption of the solutions was then determined at $540 \mathrm{~m} \mu$ by a Beckman DKIIB spectrophotometer using a blank containing no sugar. 
B. Results

1. Qualitative Analysis

a. Amino Sugars

The only amino sugar detected in all six species of fungi was glucosamine. No other sugar spots were found on the chromatograms. The $R_{F}$ values of the sugar spots are given in Table VII.

b. Simple Monosaccharides

Four sugars, fucose, galactose, glucose and mannose, were found in the fungi tested. Only glucose was found in all species. The distribution of the sugars and their $R_{F}$ values are given in Table VIII.

c. Uronic Acids

The only uronic acid found was glucuronic acid, and this occurred in all six species. The $R_{F}$ values for the sugar spots are given in Table IX.

II. Quantitative Analysis

In all determinations of the quantitative sugar composition of the six test fungi, the results were derived from the products of three separate mass cultures. Three samples of wall from each of the three cultures were hydrolysed. Three separate determinations were then carried out on each hydrolysate. Values are expressed as a percentage of the dry weight of the cell wall subjected to hydrolysis. 
TABLE V:II

RF VALUES OF GLUCOSAMINE SPOTS

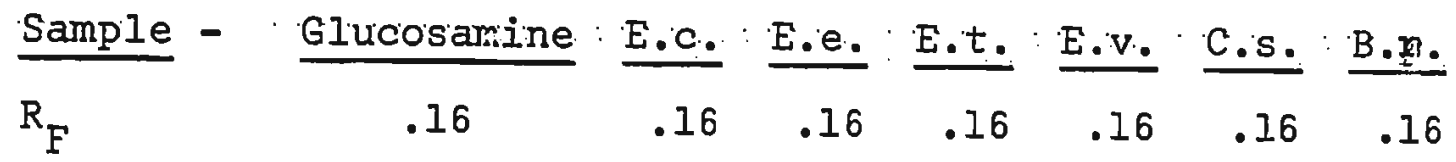

TABLE VIII

$R_{F}$ VALUES OF MONOSACCHARIDES AND THEIR DISTRIBUTION

AMONG THE F.UNGA.L SPECIES

\begin{tabular}{lcccccccc}
\multicolumn{1}{l}{ Fungus } & E.c. & E.e. & E.T. & E.v. & C.s. & B.r. \\
\cline { 2 - 4 } Glucose & .33 & .33 & .33 & .33 & .33 & .33 \\
Mannose & .39 & .39 & .39 & .39 & - & - \\
Galactose & - & - & - & - & - & .28 \\
Fucose & - & - & - & - & - & .48
\end{tabular}

TABLE IX

$R_{F}$ VALUES OF GLUCURONIC ACID SPOTS

$\frac{\text { Sample }}{R_{F}}-\frac{\begin{array}{l}\text { Glucurono- } \\ .37\end{array} \quad \text { E.c.tone }}{.37} \quad \frac{.37}{.37} \quad \frac{.37}{.37} \quad \frac{\text { E.t. }}{.37}$ 
a. Amino Sugars

The average values for glucosamine in the dry cell walls of the test fungi are given in Table $x$.

b. Simple Monosaccharides

The values for the amounts of glucose and mannose in the cell walls of the Entomophthora species are also expressed as a ratio of the percentage of glucose to that of mannose. This ratio could not be determined for Basidiobolus rariarum as the sugars were present in a small concentration that was difficult to analyse.

No ratio can be determined for Conidiobolus

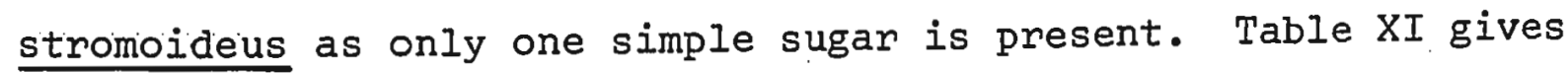
the percentage compositions of glucose and mannose in the cell walls of Entomophthora species, and the glucose:mannose ratio. c. Uronic Acids

The average values for glucuronic acid in the dry cell walls of the test fungi are given in Table XII.

d. Total Non-nitrogen Containing Sugar

The average values for total non-nitrogen containing sugar are given in Table XIII. 


\section{TABLE X}

PERCENTAGE COMPOSITION OF GLUCOSAMINE IN CELL WALLS

\begin{tabular}{|c|c|c|c|c|c|c|c|c|c|c|c|}
\hline E.c. & 8 & E.e. & 8 & $E . t$. & $q$ & E.v. & $\frac{8}{8}$ & c.s.s. & $\frac{z}{8}$ & B.r. & $\%$ \\
\hline \multirow{3}{*}{ A } & 13.13 & & 15.12 & & 16.24 & & 20.48 & & 21.26 & & 9.53 \\
\hline & 11.71 & A & 13.06 & A & 16.39 & A & 19.49 & A & 21.26 & A & 8.43 \\
\hline & 12.07 & & 14.48 & & 16.20 & & 20.78 & & 21.31 & & 10.49 \\
\hline \multirow{3}{*}{ B } & 11.24 & & 15.65 & & 16.05 & & 20.00 & & 22.17 & & 12.39 \\
\hline & 10.08 & B & 14.17 & B & 16.61 & B & 19.25 & B & 22.13 & B & 11.41 \\
\hline & 10.48 & & 14.30 & & 16.92 & & 19.91 & & 21.78 & & 13.79 \\
\hline & 10.05 & & 14.61 & & 17.91 & & 17.37 & & 25.28 & & 13.63 \\
\hline & 8.89 & C & 12.29 & C & 16.56 & C & 18.85 & C & 24.97 & $C$ & 11.83 \\
\hline & 9.67 & & 13.50 & & 17.93 & & 18.51 & & 24.72 & & 11.94 \\
\hline
\end{tabular}

Average $:$

$\begin{array}{llllll}10.81 & 14.13 & 16.75 & 19.40 & 22.76 & 11.49\end{array}$

$A, B, C=$ Individual Mass Cultures 
TABLE XI

SIMPLE MONOSACCHARIDE COMPOSITION OF THE CELL WALLS

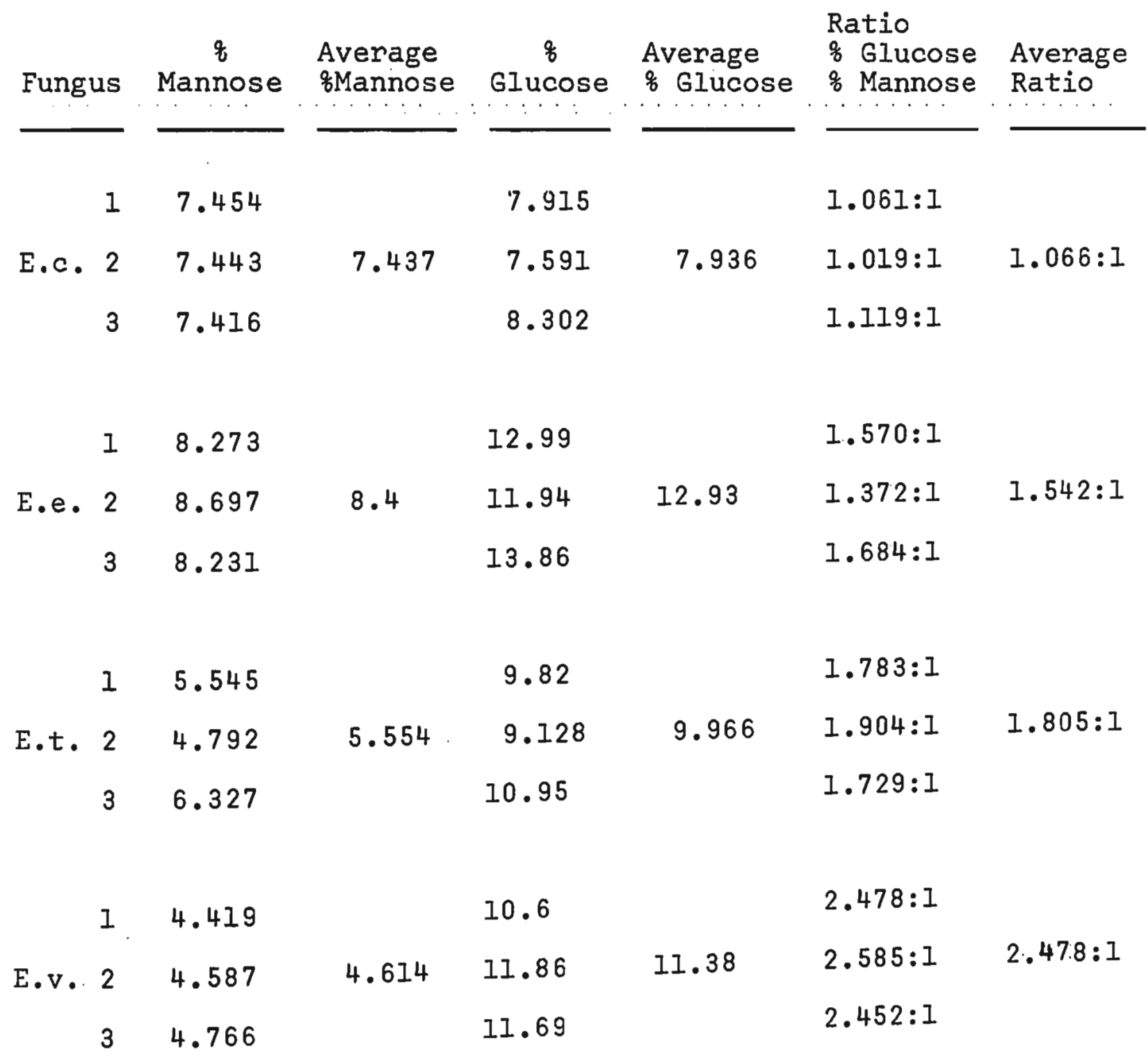

I, 2, $3=$ Separate Mass Cultures 


\section{TABLE XII}

PERCENTAGE COMPOSITION OF GLUCURONIC ACID IN CELL WALLS

Fungus $\quad$ Glucuronic Acid Average \%

1

2.635

E.c. 2

2.394

2.632

3

2.867

1

4.054

E.e.: 2

4.049

4.051

3

4.051

1

5.281

E.t. 2

5.773

5. 301

3

4.849

1

5.1 .0 .5

- E.v. 2

5. 322

5.162

3

5.059

1

2.573

C.s. 2

2.741

2.647

3

2.627

$\begin{array}{rr}1 & 3.789 \\ \text { B.r. } 2 & 3.970 \\ 3 & 3.873\end{array}$

3. 877

1, 2, and $3=$ Separate Mass Cultures 
PERCENTAGE COMPOSITION OF NON-NITROGENOUS SUGAR IN CELI WALLS

\begin{tabular}{|c|c|c|c|}
\hline Fungr & & \% Non-nitrogenous Sugar & Average $\%$ \\
\hline & 1 & 24.817 & \\
\hline E.c. & 2 & 24.000 & 24.697 \\
\hline & 3 & 25.275 & $s$ \\
\hline & 1 & 22.956 & \\
\hline E.e. & 2 & 22.755 & 23.350 \\
\hline & 3 & 24.341 & \\
\hline & 1 & 26.085 & \\
\hline E.t. & 2 & 24.944 & 25.134 \\
\hline & 3 & 24.373 & \\
\hline & 1 & 18.149 & \\
\hline E.v. & 2 & 18.944 & 18.452 \\
\hline & 3 & 18.263 & \\
\hline & 1 & 18.823 & \\
\hline C.s. & 2 & 20.353 & 20.016 \\
\hline & 3 & 20.353 & \\
\hline & 1 & 7.364 & \\
\hline B.r. & 2 & 6.068 & 6.381 \\
\hline & 3 & 5.713 & \\
\hline
\end{tabular}


CHAPTER V- THE EFFECT OF CARBON SUBSTRATES ON CELL WALL COMPOSITION

\section{A. Materials and Methods}

To determine the effect of different carbon sources on the sugars included in the cell wall, the following experiment was conducted. Using the Rosinski and Campana medium as a basis, several substitutions were made in its carbon source. In addition to the standard medium, three variants were made up.

(I) Glucose replaced by mannose (10 g)

(2) Glucose replaced by galactose (10 g)

(3) Glucose replaced by glucose, mannose and galactose ( $3.3 \mathrm{~g}$ each)

For this experiment E. coronata and E. thaxteriana were used. The conditions for growth were as before.

The fungi were harvested and the cell walls were separated by the Aronson and Machilis, 1959 mechanical method, (Section 2, IIIC). The wall material was hydrolysed by the method of Bartnicki-Garcia and Nickerson, 1962 (Section 4, Ib). Purification was by the method outlined in section 4, IIb. The simple monosaccharides released by the hydrolysis were analysed qualitatively by the method of Bartnicki-Garcia and Nickerson, 1962, (Section 4, IIIa (2)). Quantitative analysis was by the method of Wilson, 1959 (Section 4, IIIb (2)). B. Results

The simple monosaccharides were examined in the manner described for the test fungi in the test media. There was no change in the qualitative composition of the simple monosaccharides 
in either E. coronata or E. thaxteriana. The quantitative results are given in Table XIV, a and $\underline{b}$. 
TABLE XIV a

SIMPLE MONOSACCHARIDE COMPOSITION OF THE CELL WALL OF

E. CORONATA ON DIFFERENT CARBON SUBSTRATES

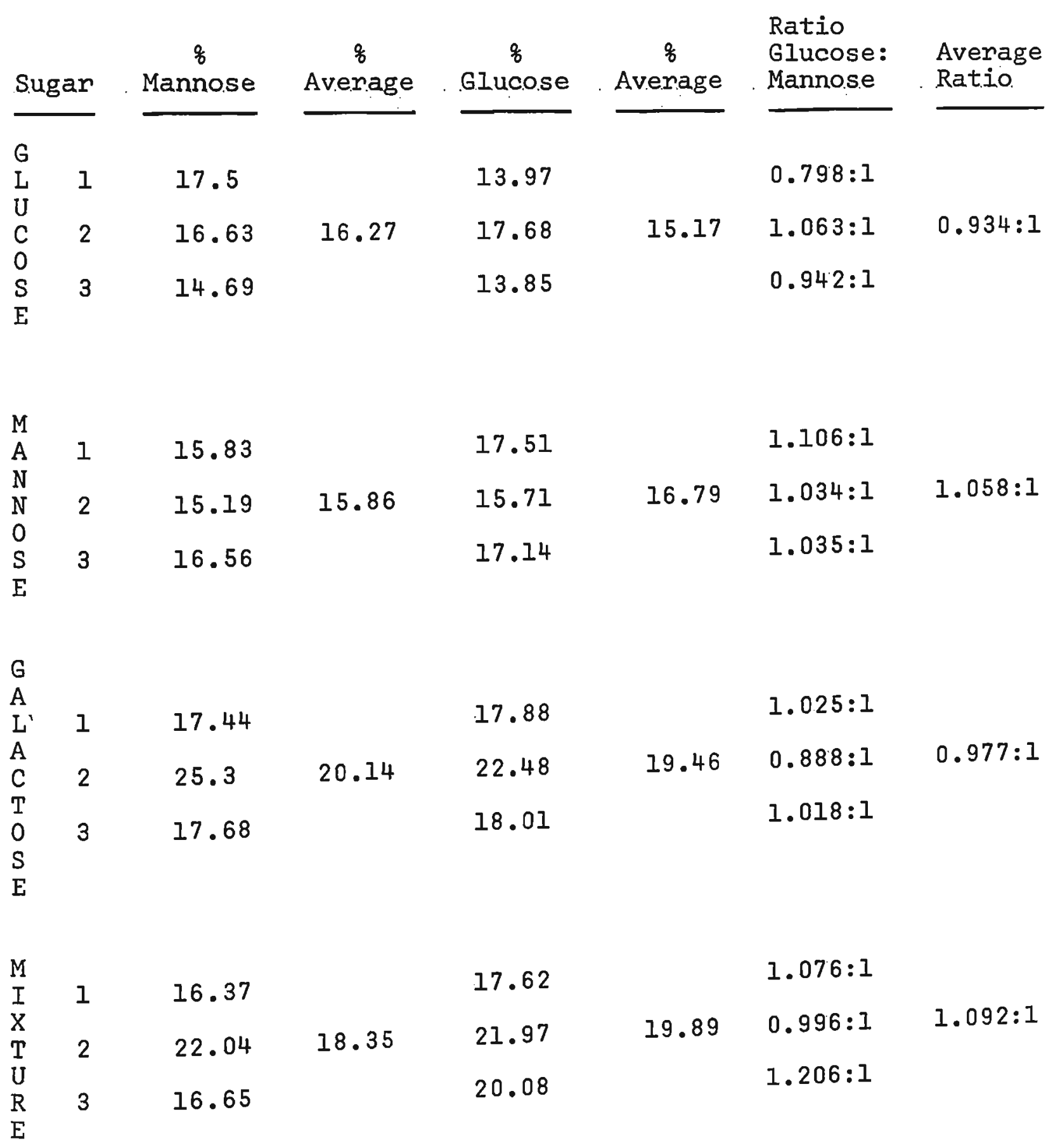

$1,2,3,=$ Separate Mass Cultures 
TABLE XIV b

SIMPLE MONOSACCHARIDES COMPOSITION OF THE CELI WALL OF

E. THAXTERIANA ON DIFFERENT CARBON SUBSTRATES

\begin{tabular}{|c|c|c|c|c|c|c|}
\hline Sugar & Maninose & $\underset{q}{\text { Average }}$ & Glucose & Average & $\begin{array}{l}\text { Ratio } \\
\text { Glucose: } \\
\text { Mannose }\end{array}$ & $\begin{array}{l}\text { Average } \\
\text { Ratio }\end{array}$ \\
\hline
\end{tabular}

G

$\begin{array}{lll}\text { L } & 1 & 12.89\end{array}$

$\mathrm{U}$$$
\text { c }
$$

$$
0
$$$$
\text { E }
$$

S

$$
213.25
$$$$
13.26
$$$$
19.06
$$

$$
21.82
$$$$
23.43
$$

$1.478: 1$

$3 \quad 13.65$

M

$$
\text { A }
$$$$
\mathrm{N}
$$$$
\mathrm{N}
$$$$
\text { S }
$$

E

$\begin{array}{lll}S & 3 & 10.18\end{array}$

E

G

L 113.46

$\begin{array}{lll}\text { A } & 1 & 12.83\end{array}$

C

\begin{tabular}{lll}
\hline & 3 & 15.09
\end{tabular}

$\mathrm{S}$

E

$\begin{array}{llllllll}M & & & & 25.04 & & 1.798: 1 & \\ \mathrm{I} & 1 & 13.92 & & 23.70 & 1.498: 1 & 1.660: 1 \\ \mathrm{X} & & & & \\ \mathrm{T} & 2 & 14.21 & 14.27 & 21.29 & 23.7 & \\ \mathrm{U} & & & & & \\ \mathrm{R} & 3 & 14.68 & & 24.76 & & \\ \mathrm{E} & & & & & & \end{array}$

$1.543: 1$

$1.634: 1 \quad 1.622: 1$

$1.689: 1$

$1.672: 1$

22.51

$21.19 \quad 1.554: 1 \quad 1,541: 1$

13.79

19.95

1. $398: 1$

21.10

$1,2,3,=$ Separate Mass Cultures 


\section{CHAPTER VI - DISCUSSION}

It was essential when selecting a medium for fungal cell production that an optimum rate of growth was produced. This was desirable from a practical standpoint to ensure an adequate and uniform supply of cell wall material. Reproducible environmental conditions and chemically defined media provided the suitable basis from which comparisons of results could be made. The main objection to the comparative study of the Polyporaceae by O'Brien and Ralph, 1966 was that they allowed their fungi to grow until they produced their maximum amount of mycelium. As a result variations in the chitin content of the cell walls used in their work may be partially explained by variations in the time taken to achieve maximum growth.

As all the media tested satisfied the requirement of producing only vegetative growth, the selection of a medium was based only on the amount of growth produced in 48 hours. The Rosinski and Campana, 1964 medium was selected because it produced the best overall growth in all of the fungi used in the experiment (Table II).

It was not possible to show temperature dimorphism in $\underline{E}$. coronata, E. exitialis; E. thaxteriana or E. virulenta at temperatures of $25^{\circ} \mathrm{C}$ and $37^{\circ} \mathrm{C}$. This contradicts the work of Johnston et al, 1967 who reported temperature dimorphism in . E. coronata at the temperatures used in this study. The isolate these workers used was obtained from a phycomycosis in a mule, 
and temperature dimorphism may be a characteristic of that isolate.

Aronson and Machlis, 1959 have emphasised the necessity for breaking down cells by mechanical means to allow quantitative analysis of their cell walls. The importance of this point is brought out by the histochemical tests on the efficiency of the separation methods. The tests on the wall material separated chemically from the cell contents indicated the presence of carbohydrates only. However, the walls prepared by the mechanical techniques of Aronson and Machlis, 1959 and Falcone and Nickerson, 1962 contained both proteins and lipids in addition to carbohydrates (Table III). Some of the proteins and lipids were present due to incomplete separation of wall and cytoplasmic fractions as demonstrated by the staining of small quantities of residual cytoplasm. Some proteins and lipids would be expected as components of the cell wall, however, as the presence of these two groups of compounds has been widely shown in fungal cell walls as pointed out in the Review of Literature.

Although no effort was made to study the proteins and lipids of the cell wall, they provided a useful indication of the integrity of the wall fraction. It was impossible to determine however if the staining was within the wall or in. the plasma membrane which might have been attached to the wall following incomplete separation. The positive reactions given by the histochemical tests for proteins and lipids showed 
that following both techniques of mechanical separation, the wall material retained its components in accordance with the observations on their distribution already cited.

The sonication method of Aronson and Machlis, 1959 was chosen for further work for several reasons. The fragments of wall material were generally larger than after grinding with glass beads, thus making separation by centrifugation easier. Also, there were no fragments of glass in the preparations. Although the glass would have remained inert through the hydrolysis and analysis stages, it would have reduced the amount of wall material weighed out $(0.02 \mathrm{~g})$ prior to hydrolysis and this could have been a source of error in later analytical work. The technique chosen also had the advantage of greater simplicity and rapidity than the technique of Falcone and Nickerson, 1962.

During the series of histochemical tests performed on the fungi under study, cellulose was not shown at any stage. Even physical techniques, i.e. birifringence could not detect it (Table V $\underline{a}$ and $\underline{b}$, Table VI $\underline{c}, \underline{d}, \underline{g l}, \underline{g I I I}$ and $\underline{\text { gIV }}$ ). Care was taken to test for cellulose after the removal of chitin (Table VI gIII and GIV). This was because Gorin and Spencer, 1968 had observed that chitin would mask the IKI- ${ }_{2} \mathrm{SO}_{4}$ test for cellulose. If the Entomophthorales are typical of the zygomycete type of wall composition, then the absence of cellulose would be 
predicted. This finding reconfirms the work of Nabel, 1939 and Frey, 1950.

The results of the test for uronic acids (Table $\mathrm{V} \underline{c}$ ) were weakly positive. It may indicate uronic acids are present but in low concentrations, and it does not rule out the possibility of their presence. Polyuronides have been reported in Mucor rouxii by Bartnicki-Garcia and Reyes, $1968 \mathrm{a}$ and they could be expected in the Entomophthorales on the basis of the affinities between these fungi.

The test for mannans is negative (Table VI $\underline{\text { e) but with }}$ the small amounts of wall material used in these histochemical studies, the technique may not have been sensitive enough to detect them. Mannans have only been shown in two families of yeasts (Table I) so their absence from the Entomophthorales is not unexpected.

Chitin was shown to be characteristic of the walls of all species tested. Its easy solubility in sodium hypochlorite and the positive chitosan test following deacetylation of the chitin by alkali, and the ready solutility of that chitosan in acetic acid, all point to chitin being a major component of the cell wall (Table VI $\underline{f}, \underline{g}, g I I)$.

Chitosan was not detected by either of the techniques employed, (Table 6 a arid $\underline{b}$ ). In both cases the experimental samples gave the same results as the controls. The controls gave negative results as they had been treated to ensure removal of any chitosan which may have been present. The chitosan test a ,after Roelofsen and Hoette, 1951, gave a red-brown 
colour with $\underline{B}$. ranarum. Jensen, 1962 has pointed out that this is a negative result and only a purple colour can be regarded as positive. The negative nature of the red-brown colour is indicated by the fact that the control, with any chitosan present removed, gave the same red-brown colour. The alternative chitosan test $\underline{b}$, after Kreger, 1954, showed no precipitate. The presence of chitosan is characteristic of the Mucorales having been shown in Phycomyces blakesleanus by Kreger, 1954 and in Mucor rouxii by Bartnicki-Garcia and Nickerson, 1962. The precipitation method used by Kreger to demonstrate chitosan was employed in this investigation. Because the presence of chitosan could not be demonstrated it is indicative that the Entomophthorales cannot be grouped with the Mucorales as chitosan-chitin fungi (Table I). On the basis of the histochemical study, only chitin can be positively identified as a polysaccharide component of the cell walls of the Entomophthorales.

Qualitative analysis of the cell walls provided useful information on the make-up of the cell walls. Glucosamine was the only amino sugar shown to be present in the cell walls of all species of fungi tested. The presence of glucosamine in the $6 \mathrm{~N}$ hydrochloric acid hydrolysates would be predicted from the results of the histochemical study previously discussed. Under the conditions used for this hydrolysis, both chitin and chitosan are broken down into monosaccharides. The chitin 
monosaccharides are, in addition, deacetylated. The results obtained in this study do not differentiate between glucosamine produced by the hydrolysis of chitin or chitosan. However, the indication from the histochemical study is that chitosan is absent from the walls and it is therefore assumed that all the glucosamine was a product of the depolymerisation and deacetylation of chitin.

The 38 nitric acid hydrolysates contained the uronic acid released from the cell wall. In all species only glucuronic acid was shown to be present. There was an indjcation in the histochemical study that pectic materials were present in the cell walls and the finding of glucuronic acid in this hydrolysate confirms this. The pink colour of the cell walls in the hydroxylamine-ferric chloride test is therefore regarded as a positive reaction.

The $1 \mathrm{~N}$ sulphuric acid hydrolysate provides the most interesting information. Conidiobolus stromoideus released only glucose in this fraction. The Entomophthora species all released glucose and mannose, thus emphasing the relationship of these

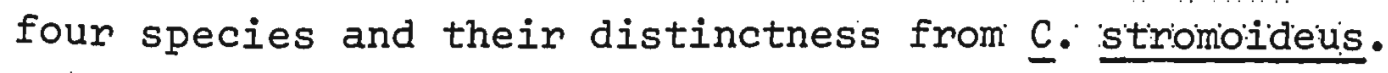
Basidiobolus ranarum released glucose, galactose and fucose from its wall. The presence of galactose is sufficient to separate this fungus from the others tested, and the additional presence of the 6-deoxy derivative of galactose, i.e. fucose, emphasises this difference. 
The qualitative analysis of the cell walls of the species under study, emphasises the validity of delimiting them in three distinct genera.

The results of the quantitative analysis of the amino sugars (Table $X$ ) suggests species specificity for the percentage of glucosamine in the walls. This percentage is only apparent however when the results of several determinations are averaged. Conidiobolus stromoideus has the highest percentage of glucosamine in its walls, sufficient to separate this fungus from the species of Entomophthora tested. The values for the four species of Entomophthora tend to form a wide range of values with some overlap of the highest and lowest percentage determinations for each species. Further work would undoubtedly show the existence of distinct percentages of glucosamine for each species, under the conditions of culture used in this experiment. It should, therefore, eventually be possible to define a species of Entomophthora. by the percentage of glucosamine in its cell wall, and to use this value to distinguish it from other species. Due to the overlap of the values for $\underline{B}$. ranarum and $\underline{E}$. coronata it is unlikely that these genera may be distinguished in this manner.

A similar argument can be extended to the percentage composition of uronic acid (Table XII). Entomophthora thaxteriana and E. virulenta both have similar values, as do E. coronata and $\underline{\text {. }}$ stromoideus. Entomophthona exitialis and B. ranarum have intermediate values between the other two pairs, but these values are not close to one another. The significance ? 
of these results is most interesting when compared with those of Tyrrell, 1967. Tyrrell, on the basis of the lipid composition of the fungi, divided the Entomophthorales into several groups. His Group I contained $E$. virulenta and $\underline{E}$. thaxteriana on the basis of the similarity of their lipids. The similarity of these fungi is again reflected in their uronic acid composition. Srinivasan and Thirumalachar, 1967, have reclassified E. coronata and $\underline{C}$. coronata on morphological grounds. On the basis of the uronic acid composition the placing of E. coronata in the genus Conidiobolus would seem justified. Tyrrell found that E. exitialis was not closely related to other species on the basis of lipid composition, and the uronic acid composition of the wall emphasises the divergence. Basidiobolus species have a different lipid composition to the other members of the order, and this difference is also evident in the uronic acid composition.

As explained in the results section, only the Entomophthora species lend themselves to useful quantitative analysis of the simple monosaccharides (Table XI). The percentage values for both glucose and mannose in the cell walls of the four species show a wide range of values, but as with the amino sugars the values are grouped according to species with some overlap of high and low values for each species. The most interesting feature to emerge from this study was that the ratio between glucose and mannose tends to be constant and 
distinct for each species. The glucose:mannose ratio may therefore be a useful criterion in developing a chemical taxonomy of the group.

The significance of the glucose:mannose ratio is emphasised in the study of $E$. coronata and $\underline{E}$. thaxteriana on a variety of substrates, (Table (XIV). Qualitatively the carbon sources used had no effect on the simple monosaccharide composition of the cell walls of either species. All the samples released glucose and mannose only on hydrolysis with $1 \mathrm{~N}$ sulphuric acid.

Quantitatively, the glucose and mannose composition is very interesting. For E. coronata on all four media tested the glucose:mannose ratios remianed approximately 1:1. For E. thaxteriana the ratio on all four media, $i: e$. approximately $1: 1.61$ is slightly lower than the original determination of 1:1.8 but from the determinations made it seems that further work would bring these ratios into line. The glucose-mannose ratio therefore not only provides a useful taxonomic criterion but it may also reduce the necessity for strictly comparable culture techniques. If so, studies of this nature could be simplified by employing the medium which gave the best growth for each fungus. More work however is required to verify this. The values given in Table XIII for the Anthrone test are probably the most accurate ones in determining the percentage of simple monosaccharides present in the cell wall. The values 
for the individual monosaccharides given by the Wilson method vary widely on either side of the Anthrone values (Tables XI and XIII). As the Anthrone test is the most sensitive method of determining the percentage of simple monosaccharides present these values should be used as a basis for comparative work. The Wilson test may have given widely different results because of difficulties in finding suitable shaking apparatus on which to grow the fungi in the early stages of this work. The Wilson test does however provide consistent glucose:mannose ratios and it seems reasonable to superimpose these ratios onto the results of the Anthrone test for non-nitrogenous simple monosaccharides in the cell walls of the Entomophthora species.

The high values given for the non-nitrogenous sugars of Entomophthora and Conidiobolus as compared to the low values in Basidiobolus again emphasises the close relationship of the first two fungi. The value for Conidiobolus stromoideus indicates that glucan is a major component of the cell wall of this fungus. On this basis the Entomophthorales should be assigned to a chitin-glucangroup of fungi distinct from the Mucorales in Bartnicki-Garcia's 1968 scheme. The Mucorales alone can be classified as chitin-chitosan fungi.

It was noted above that mannans could not be precipitated from alkali extractions of the cell wall. 'Entomophthora species therefore seem to have a heteropolysaccharide of 
glucose and mannose as a major wall component. It still seems justifiable to include the Entomophthoraceae as chitin-glucan fungi, with the reservation that the glucan component may be modified within the group by substitution.-

The classification of the Entomophthoraceae as chitin-glucan fungi may give some support to the work of Krenner, 1961. This worker included the Entomophthoraceae in the Basidiomycetes on the basis of their similar habitat responses to the Ustilaginales. The Basidiomycetes are also chitin-glucan fungi. On morphological grounds the close relationship of the Entomophthoraceae and the Basidiomycetes is unlikely.

Chitosan was not detected in the walls of any of the species tested so the inclusion of the Entomophthoriceae in a chitosan-chitin group is impossible. Barinicki-Garcia, 1968 regards the absence of glucose in the chitosan-chitin fungi as an indication that chitosan fulfills the structural role played by glucan in other fungi. The large glucan component in the cell walls of the Entomophthoraceae must clearly be fulfilling a major structural function.

From the data above it is not possible to make such definite conclusions about the Basidiobolaceae. Basidiobolus ranarum has a hyphal mode of growth which may be less susceptible to the acid hydrolysis conditions employed in tris study, than the hyphal body type of growth of the Entomophthoraceae. 
Conclusions

From the results presented in this thesis it can be stated that quantitative differences in the chemical composition of the cell wall exist at the species level in the genus Entomophthora. This is best shown by the glucose:mannose ratios. This indicates that there are significant qualitative differences in the simple monosaccharide composition of the cell walls between the three major genera of the Entomophthorales, i.e. Entomophthora, Conidiobolus and Basidiobolus.

The species specific glucose:mannose ratios could be a useful taxonomic criterion for species of Entomophthora when the ratios of more species are determined.

There are indications in this work that the grouping of various species of the order on the basis of their lipid composition is reflected in the similarity of the cell wall uronic acid composition of these species.

The classification of the Zygomycetes as chitosanchitin fungi is shown to be a generalisation. The chitosanchitin group should be limited to the Mucorales, and the Entomophthorales should be classified as chitin-glucan fungi, as chitosan was never found in the fungi tested. 


\section{REFERENCES}

Alexopoulos, C.J. 1962. Introductory mycology. John Wiley \&
Sonc, Inc., New York.

Applegarth, D.A., 1967. The cell wall of Penicillium notatum.
Arch. Biochem. Biophys. 120:471-478.

Applegarth, D.A. and G. Bozoian. 1968. The cell wall of Penicillium roquefortii. Can. J. Microbiol. 14:489-490.

Aronson, J.M. 1965. The cell wall, p. 49-76. In Ainsworth, G.C. and A.S. Sussman (Ed.) The Fungi. Academic Press,

Aronson, J.M. and L. Machlis. 1959. The chemical composition of the hyphal walls of the fungus Allomyces. Amer. J. Bot. 46:29:2-300.

Bartnicki-Garcia, S. 1962. Symposium on biochemical bases of morphogenesis in fungi (III). Mould-yeast dimorphism of Mucor. Bact. Rev. 27:293-301.

Bartnicki-Garcia, S. 1966. Chemistry of hyphal walls of Phytophthora. J. Gen. Microbiol. 42:57-69.

Bartnicki-Garcia., S. 1968. Cell wall chemistry, morphogenesis and taxonomy of fungi. Annu. Rev. Microbiol. $22: 87-108$.

Bartnicki-Garcia, S. and W.J. Nickerson. 1962. Isolation, composition and structure of filamentous and yeastlike forms of Mucor rouxii. Biochem. Biophys. Acta. $58: 102-119$.

Bartnicki-Garcia, S., and E. Reyes. 1964. Chemistry of spore wall differentiation in Mucor rouxii. Arch. Biochem. Biophys. 108:125-133.

Bartnicki-Garcia, S. and E. Reyes. 1968a. Chemical composition of sporangiophore walls of Mucor rouxii. Biochem. Biophys. Acta. 165:32-42.

Bartnicki-Garcia, S. and E. Reyes. 1968b. Polyuronides in the cell walls of Mucor rouxii. Biochem. Biophys. Acta. $170: 54-62$. 
Batko, A. 1964. Remarks on the genus Entomophthora Fresenius 1856, non Nowakowski, 1883 ( $\overline{\text { Phycomycetes, Entomoph- }}$ 12:319-321. Bull. de l'Acad. Polonaise des Sci.

Beckman, C.H. 1956. Production of pectinase, cellulase and growth producing substances by Ceratostomilia ulmi.
Phytopathology. 46: 605-609.

Chung, C.W., and W.J. Nickerson. 1954. Polysaccharide synthesis in growing yeasts. J. Biol. Chem. 208:39:5-407.

Cohn, F. 1885. Empusa muscae und die Krankheit der Stubenfliegen. 25:301-360. Acad. Caes. Leop.-Carol Germ. Nat.

Couch, J.N. 1939. A new Conidiobolus with sexual reproduction. Amer. J. Bot. 26:119-130.

Falcone, G. and W.J. Nickerson. 1956. Cell wall mannan-protein of baker's yeast. Science. 124:272-273.

Foster, J.W. 1949. Chemical Activities of Fungi. Academic Press, New York.

Fresenius, G. 1856. Notiz, Insekten-Pilze betreffend. Bot. Z. $14: 882-883$.

Frey, R. 1950. Chitin und zellulose in Pilzzellwanden. Ber. Schweiz Bot. Ges. 60:199-230.

Fuller, M.S. 1960. Biochemical and microchemical study of the cell walls of Rhizidiomyces species. Amer. J. Bot. $47: 838-842$.

Gancedo, J.M., C. Gancedo, and C. Asensio. 1966. Uronic acids in fungal cell walls. Biochem. Z. 364:328-332.

Gorin, P.A.J., and J.F.T. Spencer. 1968. Structural chemistry of fungal polysaccharides. Advances in Carbohydrate Chem. 23:367-417.

Grisaro, V., N. Sharon, and Rivka Barkai Golan. 1968. The Chemical composition of the cell walls of Penicilizium digitatium and P. italicum. J. Gen. Microbiol. 51:145-150.

Gustafsson, M. 1965a. On species of the genus Entomophthiona Fres. in Sweden. 1. Classification and distribution. Lantbrukshögkolans Ann. 31:103-212. 
Gustafsson, M. 1965b. On species of the genus Entomophthora Fres. in Sweden. II. Cultivation and Physiology. Lantbkukshögskolans Ann. 31:405-457.

Hall, I.M. and J.V. Bell. 1962. Nomenclature of Empusa Cohn and Entomophthora Fres. J. Insect. Pathol. 4:224-228.

Hall, I.M. and Dunn, P.H. 1958. Artificial dissemination of entomophthorous fungi pathogenic to the spotted alfalfa aphid in California. J. Econ. Entomol. $51: 341-344$.

Hamilton, R.B. and S.G. Knight. 1962. An analysis of the cell walls of Penicilitum chrysogenum. Arch. Biochem.

Harder, R. 1947. Thallophyten, in Lehrb. d. Botanik f. Hochschuien, bearbeitet von Fitting, Schumacher, Harder, Firbas. 23./24. Aufl. Jena.

Hutchinson, J.A. 1962. Studies on a new Entomophthora attacking calyptrate flies. Mycologia. 54:258-271.

Jensen, W.A. 1962. Botanical histochemistry. Freeman, San Francisco.

Johnston, M.J. B. Soerensen, A.M. Saliba, C. da Silva Lacaz, J.B. Neto, and J.M. Cruz. 1967. Ficomicose em muar. Isolamento da Entomophthora cororita. Arq. Inst. Biol., S. Paulo, 34:51-58.

Jonsson, A.G. 1968. Protease production by species of Entomophthora. Appl. Microbiol. 16:450-457.

Kanwar, K.C. 1967. A new adhesive techriique for micro-organisms. J. Royal Microscop. Soc. 87:483-484.

Kevorkian, A.G. 1937. Studies in Entomophthoraceae. I. Observations on the genus Conidiobolus. J. Agr. Univ. Puerto Rico. 21:191-200.

Klein, R.M. and A. Cronquist. 1967. A consideration of the evolutionary and taxonomic significance of some biochemical, micromorphological, and physiological characters in the Thallophytes. Quart. Rev. of Biol. 42:105-297. 
Kreger, D.R. 1954. Observations on cell walls of yeasts and some other fungi by X-ray diffraction and solubility tests. Biochem. Biophys. Acta. 13:1-9.

Krenner, J.A. 1961. Studies in the field of the microscopic fungi. III. On Entomophthora aphidis H. Hoffm. with special regard to the family of the Entomophthoraceae in general. Acta. Bot. Acad. Sci. Hungaricae. $7: 345-376$.

Lakon, G. von, 1963. Entomophthoraceae. Nova Hedwigia. 5:7-26.

Lanjouw, J. (Chief Ed.), and F.A. Stafleu (Sec.), Editorial Committee. 1956. International code of botanical nomenclature. Kemink en Zoon, Utrecht. 338p.

Longley, J.B. 1952. Effectiveness of Schiff variants in the periodic-Schiff and Fuelgen nucleal technics. Stain Technol. 27:161-169.

MacLeod, D.M. 1956. Notes on the genus Empusa (Cohn). Can. J. Bot. 34:16-26.

Mazia, D., P.A. Brewer, and M. Alfert. 1953. The cytological staining and measurement of protein with mercuric bromophenol blue. Biol. Bull. 104:57-67.

Mitchel, A.D., and I.E.P. Taylor. 1969. Cell wall proteins of Aspergilius niger and Chaetomium globosum. J. Gen. Microbio1. $59: 103-109$.

Nabel, K. 1939. Über die Membran-niederer Pilze, besonders von Rhizidiomyces bivellatus nov. spez. Arch. f. Mikrobiol. 10:515-541.

Novaes-Lediew, M. A. Jimenez-Martinez, and J.R. Vlllanueva. 1967. Chemical composition of hyphal wall of Phycomycetes. J. Gen. Microbiol. 47:237-245.

Nowakowski, L. 1883. Entomophthoraceae. Przycrynek doznajomosci pasorzytnych grzybkow spariajacyek pomor owadow. Pamietnic Akad. Umiejejnosci zu Krakau. 8:153-183.

O'Brien, R.W. and B.J. Ralph, 1966. The cell wall composition and taxonomy of some Basidiomycetes and Ascomycetes. Ann. Bot. (n.s.) 30:831-843. 
Olive, E.W. 1906. Cytological studies on the Entomophthoraceae. 4. Morphology and development of Empusa. Bot. Gaz.
192-208.

Percheron, F. 1967. Chromatography of carbohydrates and reReinhold, New York. In Heftmann, E. (Ed.) Chromatography.

Rizza. V. and J.M. Kornfeld. 1969. Components of conidial and Myphal walls of Penicillium chrysiogenum. J. Gen.

Roelofsen, P.A. and I. Hoette. 1951. Chitin in the cell wall of yeasts. Antonie van Leeuwenhoek, J. Microbiol.

Rosinski, M.A. and R.J. Campana. 1964. Chemical analysis of the cell wall of Ceratocystis ulmi. Mycologia.
$56: 738-744$.

Smithies, W.R. 1952. Chemical composition of a sample of mycelium of Penicillium griseofulvum Dierckx. Biochem. J. $51: 259-263$.

Srinivasan, M.C. and M.J. Thirumalachar. 1967. Evaluation of taxonomic characters in the genus Conidiobolus with a key to known species. Mycologia. 59:698-713.

Srinivasan, M.C., M.J. Narasimham, and M.J. Thirumalachar. 1964. Artificial culture of Entomophthora musciae and morphological aspects for differentiation of the genera Entomophthora and Conidiobolus. Mycologia. $56: 683-691$.

Stahl, E. (Ed.) 1965. Thin layer chromatography. Springer Verlag, New York.

Steinhaus, E.A. 1949. Principles of insect pathology. McGrawHill, New York.

Thaxter, R. 1888. The Entomophthoraceae of the United States. Mem. Boston Soc. Natur. Hist. 4:13:3-201.

Tracey, M.V. 1955. Chitin. In Paech, K., and M.V. Tracey (Eds.) Modern methods of plant analysis. Springer Verlag, Berlin.

Tyrrell, D. 1966. Fatty acids of the Entomophthoraceae (Phycomycetes) with reference to their taxonomic classification. Can. Dept. Forest. Bi-monthly Progress Rep. 22:3. 
Tyrrell, D. 1967. The fatty acid compositions of 17 Entomophthora isolates. Can. J. Microbiol. 13:755-760.

Tyrrell, D. 1968. The fatty acid composition of some Entomophthoraceae. II The occurrence of branched chain fatty acids in Conidiobolus denaeosporous Drechsl. Lipids. $3: 368-372$.

Tyrrell, D. 1969. Biochemical systematics and fungi. Bot. Rev. $35: 305-316$.

Wilson, C.M. 1959. Quantitative determinations of sugars on paper chromatograms. Anal. Chem. 31:1199-1201.

Wolf, F.T. 1951. The cultivation of two species of Entomophthora on synthetic media. Bull. Torrey Bot. Club. $78: 211-220$. 


